\title{
REGIONAL BALANCED URBANIZATION FOR INCLUSIVE CITIES DEVELOPMENT: URBAN-RURAL POVERTY LINKAGES IN SECONDARY CITIES DEVELOPMENT IN SOUTHEAST ASIA
}

Ramola Naik Singru

NO. 11

ADB SOUTHEAST ASIA

June 2015 WORKING PAPER SERIES 
ADB Southeast Asia Working Paper Series

\section{Regional Balanced Urbanization for Inclusive Cities Development: Urban-Rural Poverty Linkages in Secondary Cities Development in Southeast Asia}

Ramola Naik Singru

No. 11 | June 2015
Ramola Naik Singru

Senior Urban Development Specialist (Consultant) SEUW/SERD, ADB

This thematic background paper was presented at the International Policy Workshop on Rural-Urban Poverty Linkages, organized by the International Poverty Reduction Center in China (IPRCC) and the Asian Development Bank (ADB) supported by PRCADB Regional Knowledge Sharing Initiatives (RKSI) on 2-4 September 2014 in Hangzhou city, Zheijiang province, People's Republic of China, and financed by a regional technical assistance on Promoting Partnership for South-South Cooperation. This paper was published as part of the Southeast Asia Department Working Paper Series under the regional technical assistance TA-8314 REG - Green Cities: A Sustainable Urban Future for Southeast Asia under the Equity pillar of the $3 \mathrm{E}$ strategies (Environment Sustainability, Economic Competitiveness and Equity) of the GrEEEn Cities Approach. 
Asian Development Bank

6 ADB Avenue, Mandaluyong City

1550 Metro Manila, Philippines

www.adb.org

(C) 2015 by Asian Development Bank

June 2015

Publication Stock No. WPS157442-2

The views expressed in this publication are those of the author and do not necessarily reflect the views and policies of the Asian Development Bank (ADB) or its Board of Governors or the governments they represent.

ADB does not guarantee the accuracy of the data included in this publication and accepts no responsibility for any consequence of their use.

By making any designation of or reference to a particular territory or geographic area, or by using the term "country" in this document, $A D B$ does not intend to make any judgments as to the legal or other status of any territory or area.

ADB encourages printing or copying information exclusively for personal and noncommercial use with proper acknowledgment of ADB. Users are restricted from reselling, redistributing, or creating derivative works for commercial purposes without the express, written consent of ADB.

Note: In this publication, “\$” refers to US dollars. 


\section{CONTENTS}

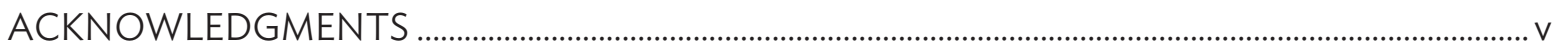

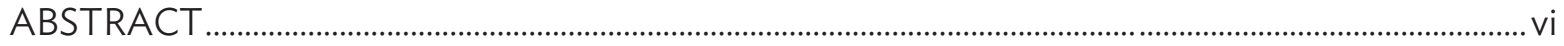

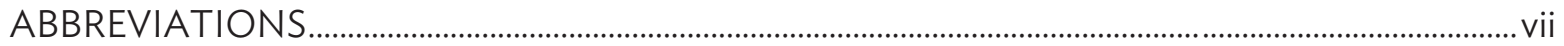

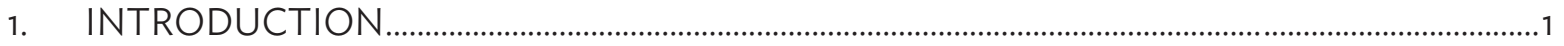

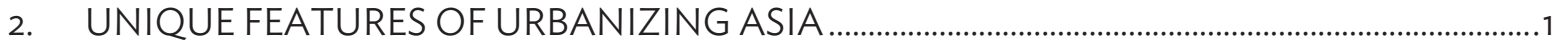

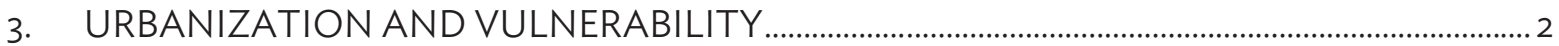

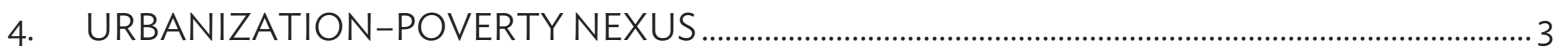

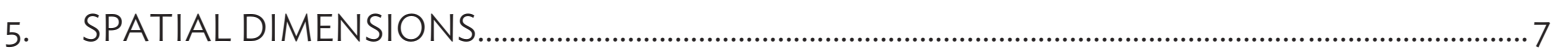

6. URBANIZATION IN SOUTHEAST ASIA,

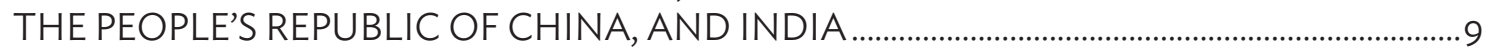

7. RESPONSE TO URBAN DEVELOPMENT CHALLENGES ............................................................. 12

8. URBAN POVERTY AND STRATEGIES FOR URBAN DEVELOPMENT IN MYANMAR ..... 14

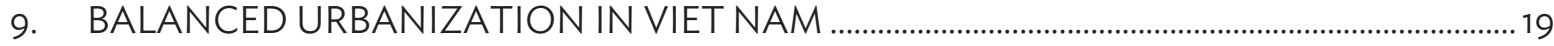

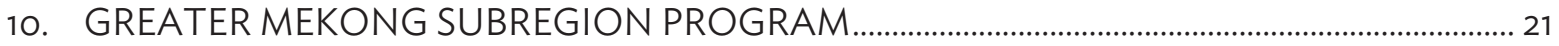

11. STRATEGIC POLICY OPTIONS FOR URBAN-RURAL INTEGRATION AND SUSTAINABLE URBANIZATION 25

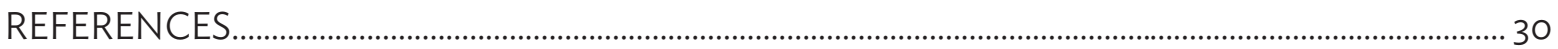




\section{TABLE, FIGURES AND CHARTS}

\section{TABLE}

1. Criteria for Classification of Urban Areas in Selected Countries .......................................................... 11

\section{FIGURES}

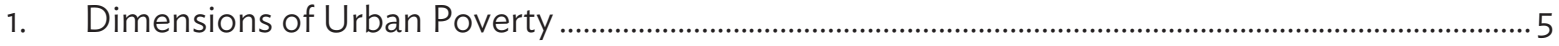

2. External factors affecting urban migrant population .........................................................................

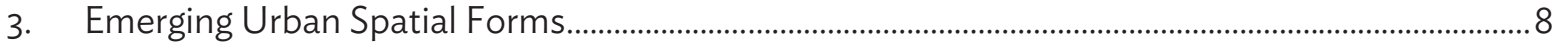

4. Country Poverty Data - Poverty headcount at \$ 1.25 and $\$ 2$ a day................................................. 12

5. Smart Systems for Integrated Urban-Rural Development................................................................. 14

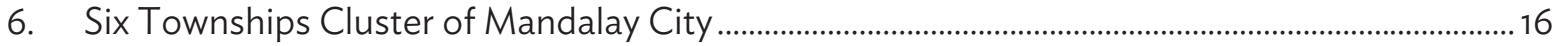

\section{CHARTS}

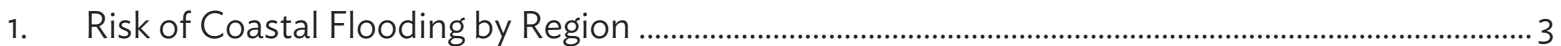

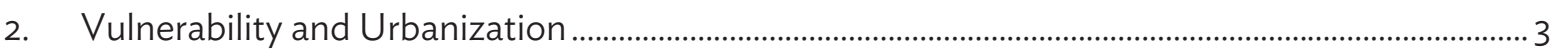




\section{ACKNOWLEDGMENTS}

This paper has been prepared by Ramola Naik Singru, senior urban development specialist (consultant), Asian Development Bank (ADB), for the International Policy Workshop on Rural-Urban Poverty Linkages, organized by the International Poverty Reduction Center in [the People's Republic of] China (the PRC). ADB supported the PRC-ADB Regional Knowledge Sharing Initiatives on 2-4 September 2014 in Hangzhou city, Zheijiang province through the regional technical assistance project on Promoting Partnership for South-South Cooperation.

The author wishes to thank Amy S. P. Leung, deputy director general, East Asia Department, ADB and Armin Bauer, principal economist, Regional and Sustainable Development Department, ADB for discussions and guidance. The author acknowledges the discussions and inputs of Sushma Kotagiri, social development specialist, Urban Development and Water Division, Southeast Asia Department (SEUW), ADB, particularly on the corridor towns and tourism projects in the Greater Mekong Subregion. The author acknowledges the inputs of Sonia Chand Sandhu, senior environment and climate change specialist, SEUW, for all the material pertaining to the Secondary Cities Development Program (Green Cities), Viet Nam, and the GrEEEn Cities Initiative. The author thanks the team members of TA-8251 MYA Towards a Green Mandalay - Alistair Blunt, Vaideeswaran S. Ninette Ramirez, and Agnes Palacio for their inputs. The author thanks the peer reviewers for strengthening the paper. This paper was published as part of the Southeast Asia Department Working Paper Series under the regional technical assistance Green Cities: A Sustainable Urban Future for Southeast Asia under the Equity pillar of the $3 \mathrm{E}$ strategies (environment sustainability, economic competitiveness, and equity) of the GrEEEn cities approach.

\section{Disclaimer:}

The views expressed in this paper are those of the author and do not necessarily reflect the views or policies of the Asian Development Bank (ADB), or its Board of Governors, or the governments they represent. ADB does not guarantee the accuracy of the data included in this paper and accepts no responsibility for any consequences of their use. Terminology used may not necessarily be consistent with $A D B$ official terms. 


\begin{abstract}
The impacts of urbanization on growth and equality, and on urban and rural poverty, are well documented, but do not discuss alternative models of urbanization. While the relationship between urbanization and growth (and poverty reduction in general) is often well established, less is discussed about the forms and causes of newly emerging urban poverty and exclusion, and how they differ for different city sizes. This paper analyzes the potential for poverty reduction with balanced regional urbanization through the development of second-tier cities and secondary towns in the Southeast Asia. It discusses the spatial growth patterns that have an impact on sustainable development and urban-rural poverty links.
\end{abstract}




\section{ABBREVIATIONS}

$\begin{array}{lll}\text { ADB } & - & \text { Asian Development Bank } \\ \text { ASEAN } & - & \text { Association of Southeast Asian Nations } \\ \text { GCA } & - & \text { Green Cities Approach } \\ \text { GCAP } & - & \text { Green City Action Plan } \\ \text { GDP } & - & \text { gross domestic product } \\ \text { GMR } & - & \text { World Bank Global Monitoring Report } \\ \text { GMS } & - & \text { Greater Mekong Subregion } \\ \text { Lao PDR } & - & \text { Lao People's Democratic Republic } \\ \text { MTDP } & - & \text { Mekong Tourism Development Project } \\ \text { PRC } & - & \text { People's Republic of China } \\ \text { SCDP } & - & \text { Secondary Cities Development Project } \\ \text { SME } & - & \text { small and medium-sized enterprises } \\ \text { UNESCO } & - & \text { United Nations Educational, Scientific and Cultural Organization }\end{array}$





\section{INTRODUCTION}

The impact of urbanization on growth and equality-and on urban and rural poverty-are well documented, but these do not discuss alternative models of urbanization. While the relationship between urbanization and growth - as well as poverty reduction in general-is often well established, less is discussed about the forms and causes of newly emerging urban poverty and exclusion, and how they differ for different city sizes. This paper analyzes the potential for poverty reduction through a regionally balanced urbanization approach using the case studies the development of secondary cities and small towns in Southeast Asian countries. It discusses the spatial growth patterns that have an impact on sustainable development and urban-rural poverty links. The paper emphasizes the equity pillar of the $3 E$ strategies of environment sustainability, economic competitiveness, and equity outlined in the GrEEEn Cities Operational Framework. ${ }^{1}$

\section{UNIQUE FEATURES OF URBANIZING ASIA}

Rapid urbanization is recognized as a defining feature of the 21st century, turning the attention toward the quality and nature of future cities and sustainable communities around the world. Asia's urbanization is unique as it is urbanizing at a pace faster than any other region, resulting in an unprecedented growth in the number of urban dwellers and increased number of densely populated megacities. The global development challenges and in particular Asia's urban challenges are daunting and often conflicting, with a rising demand for resources and services, growing consumption patterns, depleting natural resources, increasing air pollution, carbon dioxide emissions, and increasing vulnerable population exposed to climate disruptions and the rise in extreme weather events. Asian cities have to cope with the pressure on physical infrastructure, rapid environmental degradation, increasing inequality, and a reduction in social cohesion.

With about $75 \%$ of gross domestic product (GDP) today coming from the urban areas, the quality and efficiency of Asian cities will determine the region's long-term productivity and overall stability (Lindfield and Steinberg 2011). Asian urban productivity is more than 5.5 times that of rural areas but cities are also resource intensive, consuming $85 \%$ of energy, and they are polluting (Lindfield and Steinberg 2011). Sixty-seven percent of Asian (vs. 11\% non-Asian) cities fail to meet European Union air quality standard (ADB 2012). Asia alone is responsible for $35 \%$ of carbon dioxide emissions. Air pollution can have estimated $2 \%-4 \%$ negative impact on GDP.

Unprecedented growth. Asia's urbanization is unprecedented-leading to enormous challenges but with an opportunity to exploit its latecomer's advantage and unique features. From 1980 to 2010 , Asia added more than a billion people to its cities, more than all other regions combined, with a further billion set to be city dwellers by $2040 .{ }^{2}$ In 2010, for the first time in history, Asia became home to almost half of the global urban population, with $43 \%$ of its population living in urban areas. Forty-four million people are added to city population in Asia every year-equivalent to 120,000 people each day who require construction of more than 20,000 new dwellings, 250 kilometers of new roads and water infrastructure to supply more than 6 megaliters of potable water. ${ }^{3}$ This massive scale of urbanization is

S. Chand Sandhu and R. Naik Singru. 2014. Enabling GrEEEn Cities: An Operational Framework for Integrated Urban Development in Southeast Asia. Working Paper Series. No. 9, Southeast Asia Department. Manila: Asian Development Bank (ADB).

2 ADB. 2012. Technical Assistance for Green Cities-A Sustainable Urban Future in Southeast Asia. Manila.

3 ADB. 2008. Managing Asian Cities. Manila: ADB. 
taking place most notably in the People's Republic of China (the PRC), India, Pakistan, Indonesia, and Bangladesh.

Fast paced. In 2010, the urban share of Asia's population was still only $43 \%$, compared to $52 \%$ worldwide. Asia's urbanization is now rapid and fast paced, with the PRC transitioning from 10\% of its population in urban areas to $50 \%$ urban in just 60 years, versus 210 years in Latin America and the Caribbean, 150 years in Europe, and 105 years in North America. Asia's urban population is projected to continue growing faster than that of any other region (ADB 2012).

Highest densities. In total, 17 of the 25 cities with the highest population densities and 8 of the top 10 densest cities are in Asia. This growth is unique and not comparable to any other region as Asia is home to almost half of all urbanites with an urban population that is more than three times that of Europe, the region with the second largest urban population. From 2010 to 2050 the urban population in Asia will double and by then $65 \%$ of Asia's population will be urban (ADB 2011). By 2050, the urban share in Asia is projected to reach $63 \%$, gaining on but still below the $67 \%$ global average. Thus Asian cities will likely grow bigger and have even higher density.

New emerging urban forms. New forms of urbanization are emerging with mega-regions, peri-urban areas, urban corridors, satellite cities, clustered city-regions. Large cities are spreading out, engulfing nearby towns, leading to continuous belts of settlement (UN-Habitat 2009). In 2010, 12 out of 23 of world's megacities were in Asia. ${ }^{4}$

\section{URBANIZATION AND VULNERABILITY}

Cities are vulnerable to the impacts of climate change particularly rising sea level and inundation. Vulnerability will rise with urbanization. Many of Asia's largest cities, located on or close to coastal areas, will be heavily affected by rising sea levels and violent weather with a projected 410 million urban Asians at risk of coastal flooding by $2025 .{ }^{5}$ In 2000, $18 \%$ of Asian urbanites were at risk of coastal flooding, versus 11\% for Africa, 8\% for Latin America, and 7\% for Europe. In 2010, of total urban population, 251 million Asians were exposed to this risk, compared with 40 million Europeans, 32 million Africans, and 24 million Latin Americans. Manila with nearly 12 million inhabitants is the largest urban agglomeration at high risk of cyclones, floods, and earthquakes. Four other large coastal cities in Asia are at similar high risks of cyclones, floods, and earthquakes. Over 300 million were already at risk of coastal flooding in 2010, and about 250 million at risk of inland flooding such as Bangkok experienced in 2012. The number affected by inland flooding is expected to rise, to roughly 350 million by 2025. More than half the population in large cities like Ho Chi Minh City is at risk from both inland and coastal flooding. The most vulnerable and excluded in these situations are the urban poor.

4 Cities with more than 10 million population are termed as megacities.

5 United Nations, Department of Economic and Social Affairs, Population Division. 2012. World Urbanization Prospects: The 2011 Revision. New York: United Nations. 
Chart 1. Risk of Coastal Flooding by Region

Risk and Coastal Flooding by Region, 2000

\begin{tabular}{l|c|c|c|c|}
\hline Region & $\begin{array}{c}\text { Urban } \\
\text { Population } \\
\text { at Risk } \\
\text { (million) }\end{array}$ & $\begin{array}{c}\text { Share of } \\
\text { Population } \\
\text { at Risk } \\
(\%)\end{array}$ & $\begin{array}{c}\text { Urban } \\
\text { Area at } \\
\text { Risk } \\
\text { ('ooo km²) }\end{array}$ & $\begin{array}{c}\text { Share of } \\
\text { Area at } \\
\text { Risk (\%) }\end{array}$ \\
\hline Africa & 32 & 11 & 18 & 6 \\
Asia and Pacific & 251 & 18 & 129 & 11 \\
Latin America 24 & 8 & 42 & 6 & 7 \\
Europe & 40 & 7 & 56 & 7 \\
\hline
\end{tabular}

Source:

Chart 2. Vulnerability and Urbanization
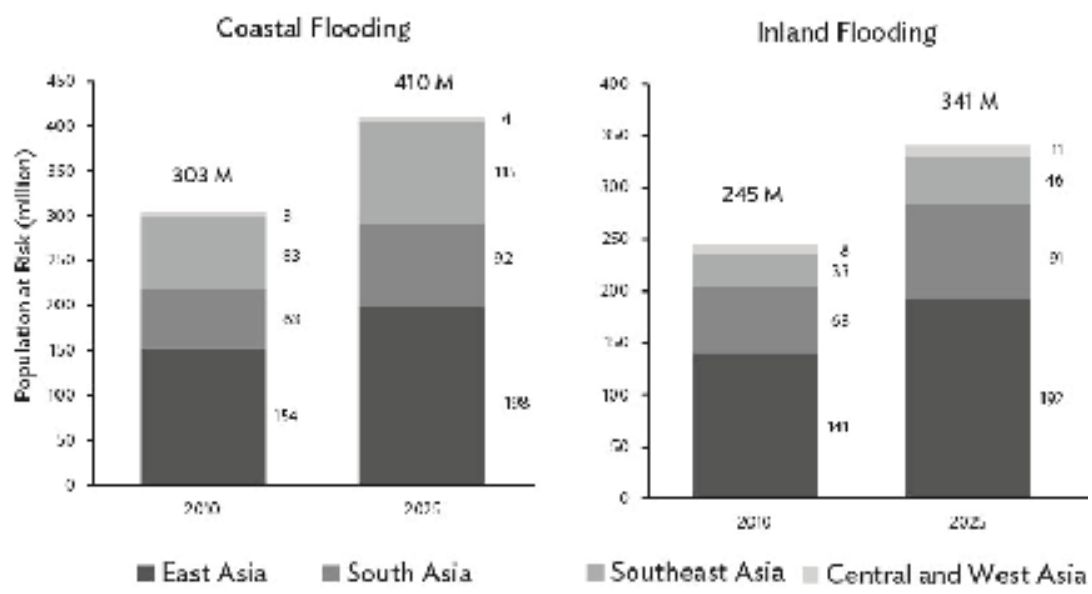

$M=$ million

Source: ADB. 2012. Key indicators 2012: Green Urbanization in Asia. Manila:

\section{URBANIZATION-POVERTY NEXUS}

Large disparities have emerged as poverty has urbanized with over 200 million people living in poverty in Asia's cities and many more are vulnerable to economic and environmental shocks (ADB 2012). The World Bank Global Monitoring Report (GMR) finds that urban poverty rates are significantly lower than rural poverty rates and that urban populations have far better access to the basic public services defined by the Millennium Development Goals, such as access to safe water and sanitation facilities, even though within urban areas asymmetries in access are large (World Bank 2013). If the forces of urbanization are not managed speedily and efficiently, growth of informal settlements can overwhelm city growth, exacerbate urban poverty, and derail Millennium Development Goal achievements. Asian cities will likely grow bigger and have even higher density. Although more than half of the megacities will be in Asia, a strong focus on the secondary cities will be required as they expand rapidly. 


\section{Urban- Rural Poverty}

With growth and urbanization, poverty also urbanizes. People are located along a continuous ruralurban spectrum, and large cities are not necessarily places where the urban poor are concentrated. Smaller towns matter greatly for urban poverty reduction and service delivery. According to the GMR, it was evidenced in a study of eight developing countries, that while the urban population was concentrated in the largest cities, incidence of urban poverty was dispersed along a continuum of medium, small, and extra small towns. ${ }^{6}$ Poverty rates measured as a share of the population below $\$ 1.25$ a day are falling in both urban and rural areas but are lower in urban area. Yet the GMR research in India indicated that while poverty is primarily a rural phenomenon at the aggregate level, urban poverty is becoming a larger problem (World Bank, 2013). Similarly, urban poverty is on the rise in the Philippines though two-thirds of the poor still live in rural areas and the rural poverty incidence is higher than the national average (Naik Singru and Lindfield 2014). The GMR found that not only is the incidence of poverty higher in small cities and towns than in the large urban areas, but these smaller urban centers also account for a larger share of the urban poor (World Bank 2013). In India, it was noted that among urban areas, poverty rates were highest in small towns (population less than 50,000 ), at $30 \%$, compared with $15 \%$ in large cities (population of 1 million or more). The size of the cities in smaller countries is comparable to small towns in large countries; hence the definition of urban poverty is essentially a function of the scale of the cities under discussion.

\section{Dimensions of Urban Poverty}

Urbanization provides greater employment opportunities. Urban productivity is more than 5.5 times that of rural areas (ADB 2012). However rising incomes in urban areas are also accompanied by a growing disparity. This is stronger in urban areas due to the income differentials. However poverty has other dimensions besides income differentials. The dimensions of urban poverty (Figure 1) annotate

the conditions that have a direct or indirect impact on the quality of life for the urban poor. ${ }^{7}$ Unless alternative approaches to address urban poverty are put in place, the poor will remain the most vulnerable.

6 World Bank. 2013. Global Monitoring Report 2013: Rural-Urban Dynamics and the Millennium Development Goals. Washington, DC: World Bank.

7 R. Naik Singru and M. Lindfield. 2015. Forthcoming. Enabling Inclusive Cities: Toolkit for Inclusive Urban Development. Manila: ADB. 


\section{Figure 1: Dimensions of Urban Poverty}

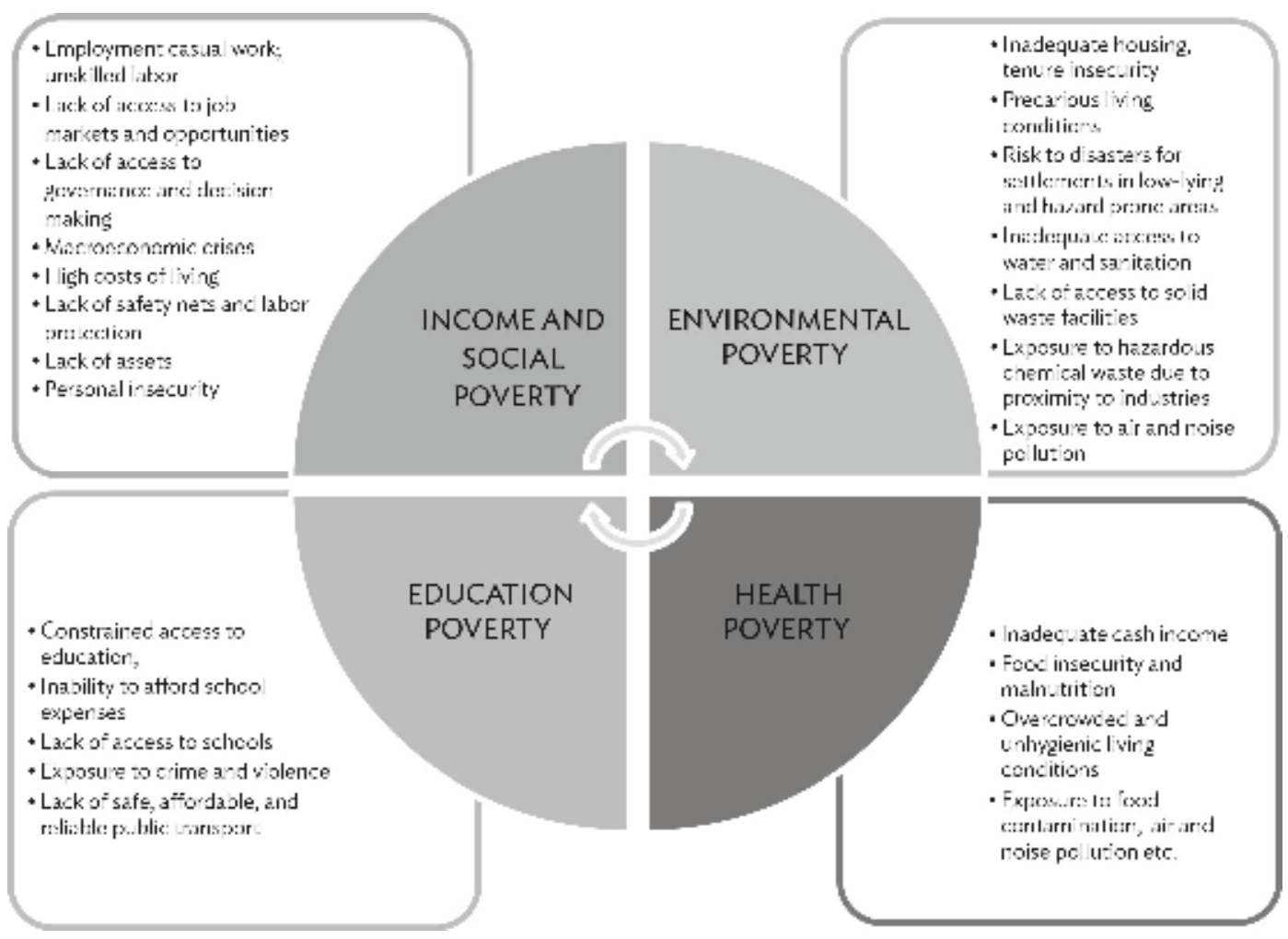

Source: R. Naik Singru and M. Lindfield. 2015. Forthcoming. Enabling Inclusive Cities: Toolkit for Inclusive Urban Development. Manila: ADB. Diagram is based on World Bank. 2002. A Sourcebook for Poverty Reduction Strategies. Vol. 2. Washington, DC: World Bank.

Migration is the major driver of urbanization in Asia. Migrants are attracted to cities with an expectation of improved conditions of living. However perceptions vary greatly from the reality. The quality of life experienced by the urban poor can be far below that in the rural areas. Urban poverty incidence in the Philippines has steadily declined with the lowest rate (10.4\% in 2006) for Metro Manila, the most urbanized region, yet the absolute number of urban poor continues to rise. A high demand for land for development leads to a worsening access to land and housing. Land prices in the growing city of Mandalay in Myanmar are much higher than might be expected for a city of a similar size in the rest of Southeast Asia.

Furthermore, low supply of affordable public housing creates urban sprawl in megacities such as Metro Manila. Policies created to alleviate situations are often counterproductive. Developers in the Philippines are required to provide $20 \%$ affordable housing units for every development they construct. However, there is no spatial binding to this regulation (Naik Singru and Lindfield 2014). The developers can provide these units anywhere in the city or outside the city boundaries leading to high scale developments in the city core and affordable or low-income units outside the city with poor connectivity and a lack of access to employment. These policies beget informal settlements as the relocated people come back to the city closer to the centers of employment. Though the share of the urban population living in informal settlements in the Philippines declined from 54.3\% in 1990 to $43.7 \%$ 
in 2009, the absolute number of inhabitants living in such settlements has steadily increased indicating a need to address urban renewal through targeted investments (Naik Singru and Lindfield 2014).

Informal settlements are often built in high-risk areas with no access to basic urban services such as water supply, sanitation, and solid waste facilities. With the growing intensity and frequency of natural disasters such as flooding, cyclones, and typhoons, this urban poor population is vulnerable to greater risks. Though access to basic services in informal settlements has tended to improve over time, typically areas such as front railways and riverbanks are making provision of basic urban services problematic in these settlements. Worsening access to services contributes to overcrowded unhygienic living conditions and environmental degradation including pollution of water bodies such as rivers, canals, and lakes. Furthermore, a large portion of the urban population lives barely above the poverty line, and these individuals are vulnerable to slipping back below it due to loss of employment, illness, natural disasters, or other factors affecting income levels.

The safety nets in the rural areas - ability to grow food, access to natural resources, proximity of family and friends, among others-enable the rural poor to cope through crisis. However, in urban situations, more income is spent on survival services such as water, food, housing rent, and commuting. Inadequate housing, tenure insecurity, precarious living conditions, risk to disasters for settlements in low lying and hazard prone areas, inadequate access to water and sanitation, lack of access to solid waste facilities, exposure to hazardous chemical waste due to proximity to industries, exposure to air and noise pollution, exposure to food contamination, food insecurity, and malnutrition are some of the factors that make urban poverty more acute than rural poverty.

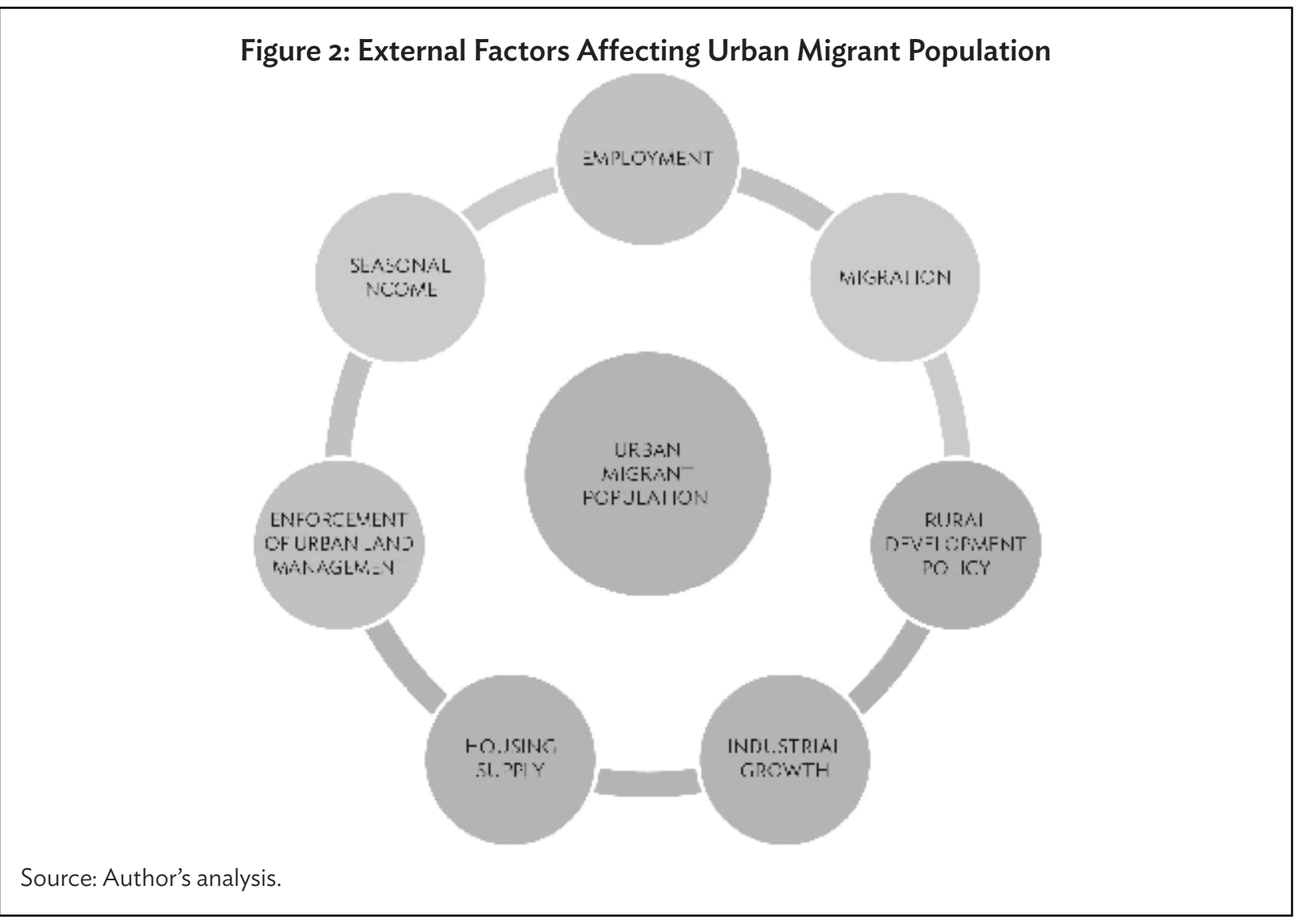




\section{SPATIAL DIMENSIONS}

New forms of urbanization are emerging with mega-regions, peri-urban areas, urban corridors, satellite cities, clustered city-regions. A total urban population of 3.3 billion is unevenly distributed across the world in urban agglomerations of different sizes. More than $52 \%$ of the world's urban population and $51 \%$ of urban population in developing countries reside in cities and towns of less than 500,000 people (UN-Habitat 2009). Large cities are spreading out, engulfing nearby towns, leading to continuous belts of settlement. In 2010, 12 out of 23 of world's megacities were in Asia. ${ }^{8}$ By 2025, the number of megacities in Asia is expected to increase to 21 out of a global total of 37. The additional Asian cities include: Chongqing, Tianjin, and Wuhan in the PRC; Bangalore, Chennai, and Hyderabad in India; Jakarta in Indonesia; Bangkok in Thailand; and Lahore in Pakistan. In 2025 it is expected that more than 37 megacities worldwide and 22 of those will be in Asia while there are expected to be more than 500 cities with more than 1 million inhabitants (ADB 2012). Unplanned urbanization through megacity expansion creates many problems for poverty reduction and inclusive growth.

\section{Forms of Urban Expansion}

With economic and demographic growth, the urban agglomerations expand spatially-vertically through urban densification and horizontally through metropolitanization, peri-urbanization and urban sprawl. These spatial forms of physical expansion have an impact on the ability of the city to meet the needs of its expanding population. Increasingly, urban managers and planners are grappling with providing urban infrastructure and services to an expanding population spread across new spatial forms. Various forms of spatial expansion of urban agglomerations are listed:

(i) Vertical expansion

(a) Urban densification: higher floor space index and/or floor area ratio, high rise buildings;

(b) Mixed-use: Diversification and combination of land uses to increase self-sufficient urban areas and limit urban sprawl; and

(c) Transit oriented developments: mixed-use developments around a transit hub.

(ii) Horizontal expansion

(a) Metropolitanization: clustering of adjoining towns to form a contiguous metropolitan city or megacity.

(b) Radial expansion

(1) Peri-urban: an area developed beyond an urban boundary and the rural area,

(2) Suburban: a predominantly residential development abutting a city,

(3) Satellite towns: towns developed through a symbiotic relationship in close proximity to large cities,

(4) Urban villages: villages enclosed through city expansion, and

(5) Clustered development: cluster of small urban townships forming a city core.

(c) Linear expansion-Corridor towns development: towns and cities connected along a fasturbanizing linear transport and industrializing corridor to expand economic opportunities.

8 Cities with more than 10 million population are termed as megacities. 


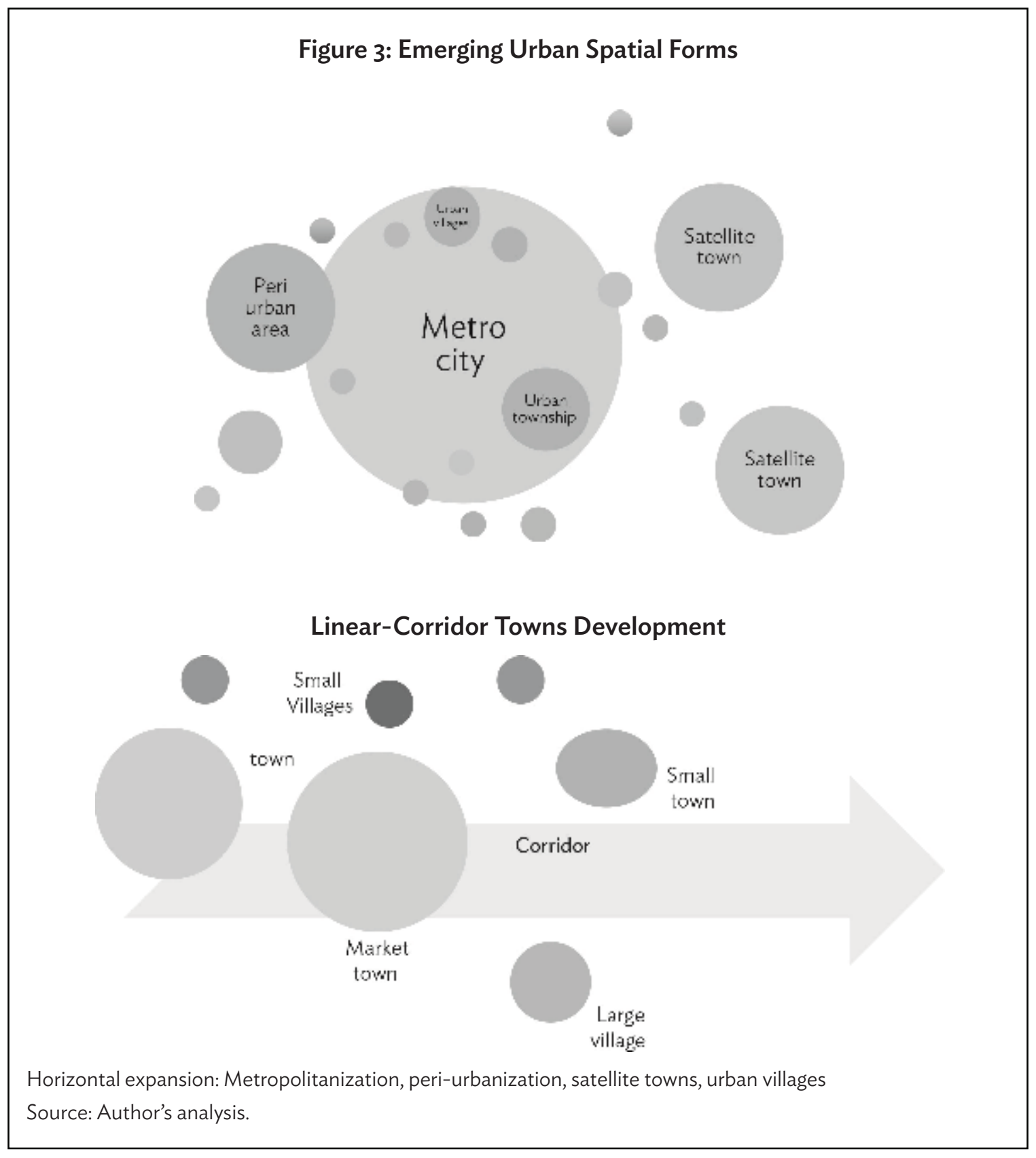

The globalization of economic activity has been a catalyst for change in the spatial and social reorganization of cities evident through distinct socio-spatial forms like increased social polarization, spatial segregation, and gentrification processes. Socio-spatial transformations in the developing countries are primarily in the direction of spatial segregation, fragmentation, and specialization of functions and land-uses in cities (Naik Singru 2007). With the push factor being greater than the pull factor, there is likely to be an increase in migration to the urban centers of rural labor in search of livelihoods that sustain not only the migrating population but also their rural families left behind in the villages. Though the cost of city living is too high to support an entire family in the city, the rural households find the meager remittance amount sufficient to sustain themselves in the villages (Naik Singru 2008b). Thus, in an increasingly global and interlinked economy, the rural and urban are no 
longer distinctly separate economic zones. The interdependence of the urban-rural economies and its consequences necessitates an increased interest in urban-rural linkages that can help in redefining urban development policy (Naik Singru 2008). Urbanization has abetted growth but begets inequality. Inequality in the urban space is experienced through the lack of access to shelter and services. In many cities in developing countries, spatial forms are largely driven by the efforts of low-income households to secure land that is affordable and in a reasonable location, often in peri-urban areas where the rural areas merge with the expanding cities.

A better urban-rural integration and small towns development can be a driver of change to address many problems of poverty, migration, and environmental degradation in Asia. Sattherthwaite and Tacoli (2003) have documented well the crucial role small and intermediate urban centers can have in the economic development of their surrounding region: for example, local urban markets can link producers to national and international markets and thereby increase rural incomes; the concentration of the production and distribution of goods and services in local urban centers can decrease costs and improve access; and the demand for nonfarm workers can improve rural households' incomes and decrease migration pressure on the larger urban centers. Urban centers such as towns, market towns, secondary cities, and megacities progressively scale up the connectivity links of transport and services for the supply-chain management.

Enhancing urban-rural linkages is mutually beneficial as rural areas are supply sites and producers of food, material, natural resources, labor, as well as sites of recreational and health tourism particularly in the Southeast Asian countries of Cambodia, Indonesia, Lao People's Democratic Republic (Lao PDR), the Philippines, and Viet Nam. Economies that depend on nature, such as fishing, and recreational and health tourism require better connectivity and transport infrastructure to exploit its commercial value. These are seasonal and increasingly fragile economies in coastal areas exposed to increasing environmental impacts and climate induced events.

Facilitating movement of people, goods, services, natural produce, and resources requires better transport infrastructure and connectivity. This includes provision of facilities and telecommunication infrastructure that enables rural populations to access information and services to meet the needs of the urban markets to gain a fair and faster compensation for their services while based in their rural settings. Furthermore, the reduced need for travel with telecommunications and increased livelihood opportunities in rural areas can contribute to environmental, social and economic co-benefits.

\section{URBANIZATION IN SOUTHEAST ASIA, THE PEOPLE'S REPUBLIC OF CHINA, AND INDIA}

\section{Understanding Urban}

Urban is defined within the geographical context of a country. It can be a misnomer if used as a comparator between countries that are small in population and geographic area such as the Mekong countries, with those that are large in both population and area such as the PRC and India. As analyzed by the GMR, small towns in small countries are significantly smaller than the small towns in large countries (World Bank 2013). Many small countries do not have a megacity, and nearly all large countries have many large cities of various sizes as well as one or several megacities. It is difficult to make accurate international comparisons of the proportion of nations' population living in small urban centers defined by their population size because each nation has its own criteria for determining when 
a settlement is large enough to be classified as urban. Each country defines its own criteria to determine whether a settlement is classified as urban based on population size, administrative status or governance, concentration of non-agricultural employment base, and density of population (Sattherthwaite and Tacoli 2003). With regard to population threshold being used in the definition of an urban center, these can range widely: in the Philippines, settlements with a population of more than 1,000 are eligible for urban status, while the threshold in Viet Nam is over 4,000 (Sattherthwaite and Tacoli 2003). In understanding and comparing urbanization with a view to planning and provision of infrastructure it is rational to base any comparative analysis on population size of the agglomeration.

Urban in Viet Nam is classified as per the Decree No. 72/2001/ND-CP for classification of urban centers and urban management levels (Government of Viet Nam, 2001). Urban centers include cities, provincial towns, and district townships established under decisions of competent state agencies. Urban centers are classified into six grades, namely: special-grade, grade-I, grade-II, grade-III, grade-IV and grade- $\vee$ urban centers. The basic factors for classifying urban centers include:

(i) The function of being general centers or specialized centers, and the role of boosting the socioeconomic development of the whole country or a certain territorial area;

(ii) The non-agricultural labor represents at least $65 \%$ of the total labor force;

(iii) The infrastructures in service of population's activities must be at least $70 \%$ up to the standards and norms prescribed for each type of urban centers;

(iv) The population size must be at least of 4,000 people; and

(v) The population density conforms to the size, nature and characteristics of each type of urban centers.

Further the decree defines the urban management levels as:

(i) Centrally-run cities;

(ii) Provincially-run cities, provincial towns or centrally-run cities and/or towns; and

(iii) District townships.

For the census of India 2011, the definition of urban area is as follows:

(i) All places with a municipality, corporation, cantonment board or notified town area committee, etc.; and

(ii) All other places, which satisfy the following criteria:

(a) A minimum population of 5,000;

(b) At least $75 \%$ of the male main working population engaged in non-agricultural pursuits; and

(c) A density of population of at least 400 persons per square kilometer.

The first category of urban units is known as statutory towns. These towns are notified under law by the concerned state and/or union territory government and have local bodies like municipal corporations, municipalities, and municipal committees, irrespective of their demographic characteristics as reckoned on 31 December 2009. 
In the Philippines the classification is based on administrative or political units. A barangay is the smallest political unit in the Philippines. Generally, one enumerator is assigned to enumerate one barangay. For enumeration purposes, a large barangay is usually divided into parts, and each part is called an enumeration area. A barangay is classified as urban if it meets any of the following:

(i) It has a population size of 5,000 or more;

(ii) It has at least one establishment with a minimum of 100 employees;

(iii) It has five or more establishments with 10 to 99 employees, and five or more facilities within the two-kilometer radius from the barangay hall.

The level of urbanization in 2010 or the proportion of urban population to the total population in the Philippines was $45.3 \%$. This means that of the 92.3 million population in the Philippines in 2010, 41.9 million lived in areas classified as urban. The rural population or those who lived in areas classified as rural numbered 50.5 million and accounted for $54.7 \%$ of the total population (National Statistics Office 2010).

Urban settlements in the PRC were administratively defined as statutory cities and statutory towns until 2006. Since, they have evolved to a five-tier structure based on their administrative status as central, provincial, prefectural, county, city, and township (or community in cities). This limited criteria for classification makes comparisons difficult.

Table 1: Criteria for Classification of Urban Areas in Selected Countries

\begin{tabular}{|c|c|c|c|c|}
\hline Country & $\begin{array}{l}\text { Minimum } \\
\text { Population }\end{array}$ & $\begin{array}{c}\text { Density } \\
\text { (persons per } \\
\text { square kilometer) }\end{array}$ & Administrative Status & $\begin{array}{l}\text { Non-Agricultural } \\
\text { Employment Base }\end{array}$ \\
\hline India & 5,000 & 400 & $\begin{array}{l}\text { Statutory towns; all places } \\
\text { with a municipality, } \\
\text { corporation, cantonment } \\
\text { board, or notified town area } \\
\text { committee, etc. }\end{array}$ & $75 \%$ (male) \\
\hline $\begin{array}{l}\text { The People's } \\
\text { Republic of China }\end{array}$ & - & - & $\begin{array}{l}\text { Five-tier structure: central, } \\
\text { provincial, prefectural, } \\
\text { county, city, and township } \\
\text { (or community in cities) }\end{array}$ & - \\
\hline Philippines & 5,000 or more & - & - & $\begin{array}{l}\text { At least one } \\
\text { establishment with } \\
100 \text { employees } \\
5 \text { or more establishments } \\
\text { with } 10 \text { to } 99 \text { employees, } \\
\text { and } 5 \text { or more facilities } \\
\text { within the 2-kilometer } \\
\text { radius from the barangay } \\
\text { hall }\end{array}$ \\
\hline Viet Nam & 4,000 & - & $\begin{array}{l}\text { Centrally run, provincially } \\
\text { run, district }\end{array}$ & $65 \%$ \\
\hline
\end{tabular}

$-=$ not available.

Source: Author's analysis. 


\section{Urban-Rural Poverty Linkages in Southeast Asia, the PRC, and India}

Urbanizing Asia is rapidly rising. However urbanization, while potentially contributing to poverty reduction, is not solving the problems of inclusive growth and persistent poverty in Asia. ${ }^{9}$ Poverty eradication goals are established in measuring it against an estimated poverty incidence at $\$ 1.25, \$ 2$, and $\$ 3$ international poverty line. Country poverty data for selected Southeast Asian countries was compared with that in India and the PRC. In most cases the estimated poverty incidence at $\$ 2$ a day is more than double the headcount at $\$ 1.25$ a day (Figure 4 ).

\section{Figure 4: Country Poverty Data - Poverty Headcount at $\$ 1.25$ and $\$ 2$ a day}

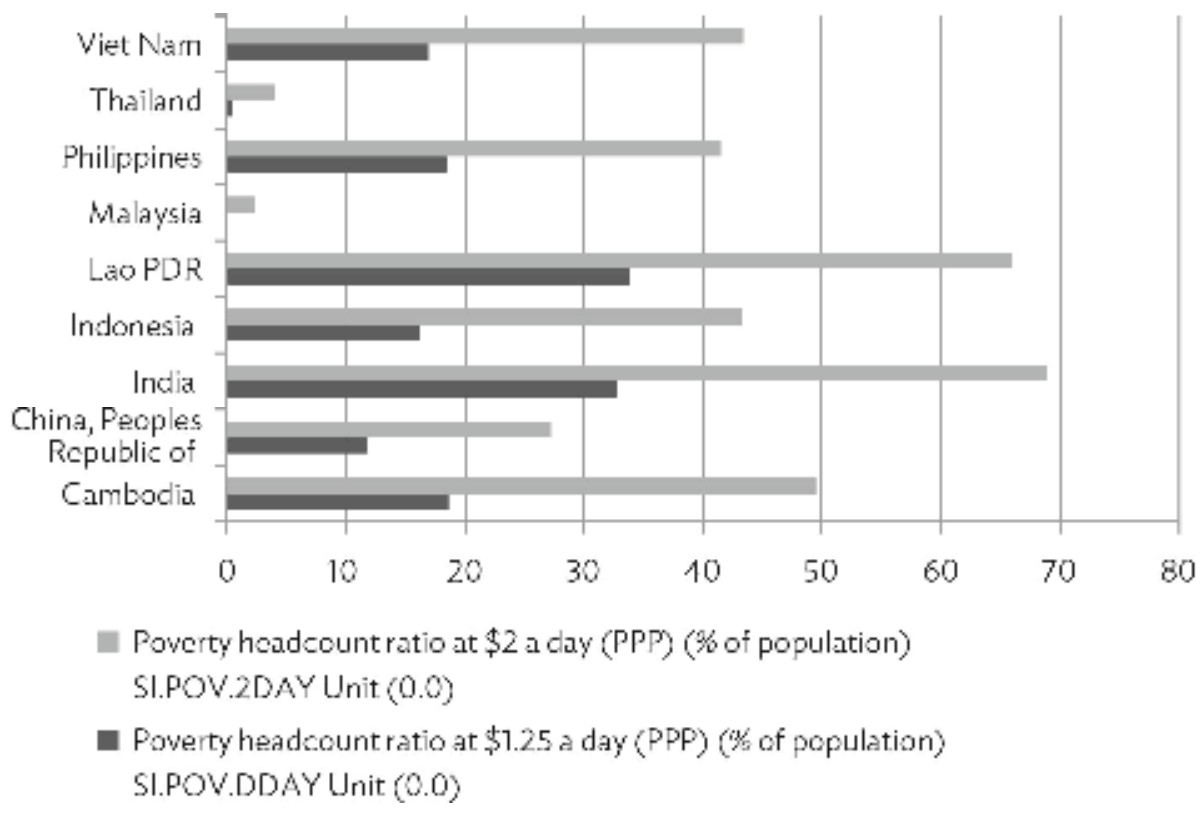

Lao PDR = Lao People's Democratic Republic, PPP = purchasing power parity, SI.POV.DDAY = Poverty headcount ratio at $\$ 1.25$ a day (PPP) (\% of population)

Source: Author's analysis based on World Bank 2014, Poverty and Inequality Database.

However, the measures of poverty need to consider the conditions of "livability" or the quality of life available in the urban or rural areas for policy considerations. Urbanization is putting strains on the environment, affecting the quality of life for everyone, particularly the poor. Poverty, disparities in wellbeing, environmental pressures, as well as climate change remain the key issues confronting the Asia and Pacific region. Moreover, urban populations are exploding, and the challenge lies in our ability to respond to these needs. The following sections capture few examples from the Asian Development Bank's (ADB) response to urban development challenges in Southeast Asia.

\section{RESPONSE TO URBAN DEVELOPMENT CHALLENGES}

The Urban Operational Plan, 2012-2020, of ADB provides direction for ADB's response to the challenge of rapid urbanization by supporting investments in sustainable urban development based on the $3 \mathrm{E}$ strategies of economic competitiveness, environmental sustainability, and equity. An integrated

9 See: O.P. Mathur. 2013. Urban Poverty in Asia. Manila: ADB. http://www.scribd.com/doc/174976062/Mathur-Aug-2013Urban-Poverty-in-Asia-final-2 
approach to urban development will ensure sustainable and livable cities that are competitive, inclusive, and green. Competitive cities focus on the roles and contributions of economic clusters in the broader context as fundamental to designing a value-adding approach to inclusive economic development.

GrEEEn Cities Approach (GCA) is a flexible and scalable initiative that proposes a paradigm shift in response to rapid urbanization by integrating urban development with environmental planning to improve livability and resilience in cities. ${ }^{10}$ Through the GrEEEn Cities Initiative for Southeast Asia, ADB is working with cities that commit to a long-term partnership (15-20 years) and have long-term vision for their urban development. This allows ADB to support developing member countries to move from green growth strategies to green city realities. ADB will work with cities to take $3 \mathrm{E}$ strategies from theory to practice by developing green city action plans and urban management partnerships that help to identify projects, and develop creative financing modalities.

The equity pillar under the GCA promotes inclusive urban development based on the underlying principles of accessibilty, affordability, resilience, and sustainability. ${ }^{11}$ Inclusive cities is an integrated approach encompassing sustainable, resilient, accessible, and affordable solutions to the challenges faced by the urban poor and vulnerable groups by enhancing their access to urban services and infrastructure through targeted investments such as participatory planning, informal settlement upgrading, urban housing, resilient urban infrastructure, community services, and livelihood development. This integrated approach encourages an institutional planning and delivery mechanism that brings together all institutions and stakeholders-government, private sector, civil society-who have the capacity to deliver systems for inclusive urban service delivery. The approach proposes that the capacity of the urban poor communities, informal settlement networks, and nongovernment organizations should be effectively used in conjunction with the city government and private sector.

\section{Smart Systems}

As stated in ADB's Strategy 2020, "To transform the archetypical chaotic, polluted, inequitable city of Asia into a competitive, equitable and environmentally sustainable urban region-in short, a livable city-will require a new approach to city development and to ADB's support for that development. Core to the transformation is a new emphasis on the need for an integrated planning approach to the provision of environmental infrastructure and services and other public goods."12

A smart systems approach for integrated planning and urban-rural development is one that envisions urban challenges from a holistic perspective by integrating the rural issues as part of the urban system. A smart system or an intelligent system is a management platform using information technology and institutional coordination for effective implementation of programs through enabling synergistic interlinkages of the following themes:

(i) Integrated Planning and Management;

(a) Land management,

(b) Industrial growth,

(c) Urban expansion,

10 S. C. Sandhu, and R. Naik Singru. 2014. Enabling GrEEEn Cities: An Operational Framework for Integrated Urban Development in Southeast Asia. Working Paper Series No. 9. Southeast Asia Department, Manila: ADB .

1 R. Naik Singru and M. Lindfield. 2015. Forthcoming. Inclusive Cities Toolkit. Manila: ADB.

12 ADB. 2008. Strategy 2020: The Long-Term Strategic Framework of the Asian Development Bank 2008-2020. Manila. 
(ii) Urban-Rural Linked Policies;

(iii) Smart Governance;

(iv) Innovative Financing; and

(v) Strengthening Institutional Structures and Capacity.

Figure 5: Smart Systems for Integrated Urban-Rural Development

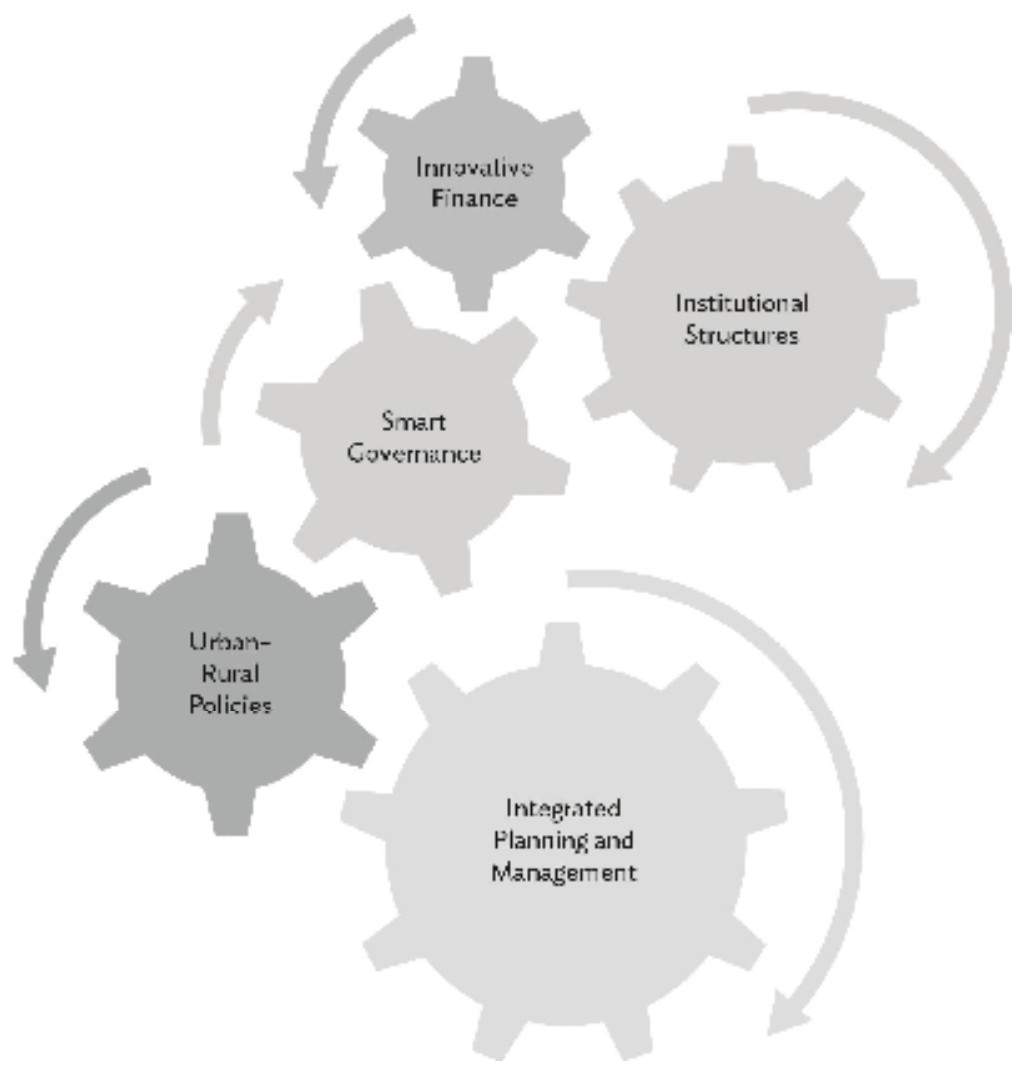

Source: Author's analysis.

\section{URBAN POVERTY AND STRATEGIES FOR URBAN DEVELOPMENT IN MYANMAR}

Myanmar is undergoing rapid change as it has begun a period of transition from a very centralized military-dominated system of government that is command-led, to one that is primarily civilian and democratic. This change is also accompanied by the opening up of the country to international trade and investment, which is expected to stimulate very rapid economic growth in the next decade or more. Myanmar's population is approximately 60 million, estimated in 2010 to be increasing about 1.3\% annually while the annual urban growth rate is estimated at $2.9 \% .{ }^{13 \& 14}$ This is comparatively high

13 There has not been a census for the past 2 decades, hence the demographic estimates are approximate. Quoted in ADB. 2012. Republic of the Union of Myanmar Initial Assessment of Urban Development and Water Sector. Manila.

14 Government of the Union of Myanmar. 2010. Statistical Year Book. . Nay Pya Taw: Ministry of National Planning and Economic Development. 
compared with other countries in the Association of Southeast Asian Nations (ASEAN). In 1983, the urban population made up less than 25\% of the total population, of which $32 \%$ were found in Yangon region (Blunt et al 2014). Approximately one-third of Myanmar's population is classified as living in urban centers, comparable to that of Thailand (34\%) but much lower than that of Malaysia (72\%).

\section{Urban Population and Regional Context}

The official capital is Nay Pyi Taw, located midway between Myanmar's two largest cities-Yangon with a population of about 4.6 million and Mandalay with a population of about 1.0 million. The third largest city is Mawlamyine (population of about 500,000), after which city size rapidly falls: there are only 31 urban centers with population of more than 100,000. The urban centers are largely concentrated in the low-lying regions of the central dry zone and the coastal areas. Mandalay is the second largest city in Myanmar with a population estimated to be over 1.3 million and with a historic growth rate of just over $2 \%$ per year. However, with the opening up of the country to outside investment, and with its critical location as on the crossroads of links between the PRC and the Bay and Bengal and the routes between Cambodia, the Lao PDR, and Viet Nam with India, it is seen to grow at a far faster rate of nearer $3 \%$ over the next 25 years, resulting in a population of over 3 million by 2040 (ADB 2014). With the improved economic opportunities, the resulting increase in foreign direct investment, and increased importance of the role of Mandalay, it is probable that the city should be planning for a far greater population of more than 3 million by 2040.

In 2013, ADB provided a capacity development technical assistance ${ }^{15}$ to support the Ministry of Construction to prepare a scoping study for a Strategic Development Plan for Green Mandalay, which could act as a model for the management of urban development throughout Myanmar. The outputs of the study "Toward a Green Mandalay" is informing the design of the investment loan for the urban services improvement project, financed by ADB (ADB 2014). The study was the first attempt at establishing a baseline understanding of the quality of life issues in the city of Mandalay.

\section{Spatial Structure of Clustered Villages}

Mandalay city came to be formed through the clustering of rural villages which expanded to townships as the city expanded horizontally. Mandalay consists of six townships, which are divided into 96 wards, 42 village tracts, and 170 villages. Land uses show that $46.5 \%$ of the Mandalay city is urban, and the remaining parts are rural (41\%) or water bodies (almost 10\%) and villages (less than 3\%). While Pyi Gyi Dagon was rural as the 1990s, it has since become predominantly urban. In March 2011, Amarapura was absorbed into Mandalay city, giving it a total area of 121.5 square miles, 16.5 miles from east to west and 16 miles from north to south. The greatest part of the agricultural land and water bodies and most of the villages are found the Amarapura. In the urban areas, land is predominantly government land or land for public utilities, with only $24 \%$ freehold or leasehold.

15 ADB. 2013. Technical Assistance to Myanmar for Capacity- Building Support for Project Identification. Manila. 


\section{Urban Poverty Estimates}

The first household socioeconomic survey was undertaken for 600 households in the six townships. The team organized two stakeholder consultation workshops. The first workshop reviewed the findings presented in the urban profile and through a systematic system of scoring the impact of the issues identified on the green city criteria of Mandalay, provided a further evaluation of the critical issues that need to be tackled to achieve the objectives of developing Mandalay as a green city. The second was to prioritize the proposed solutions and to identify additional strategies to achieve, to ensure green development of the city and regional corridor development. Questions regarding household income and expenditures were included in the socioeconomic survey conducted in order to establish an indicative financial capacity data of the people in the six townships. Based on the result of the socioeconomic survey, the average monthly household income is about Myanmar MK382,000 (about $\$ 389$ ) or about $\$ 67$ per capita equivalent, and the median income is about MK300,000, (\$306) and the per capita income $\$ 53$. Estimates suggest that about $25.6 \%$ of people in Myanmar are living below the national poverty line in $2010 .^{16}$

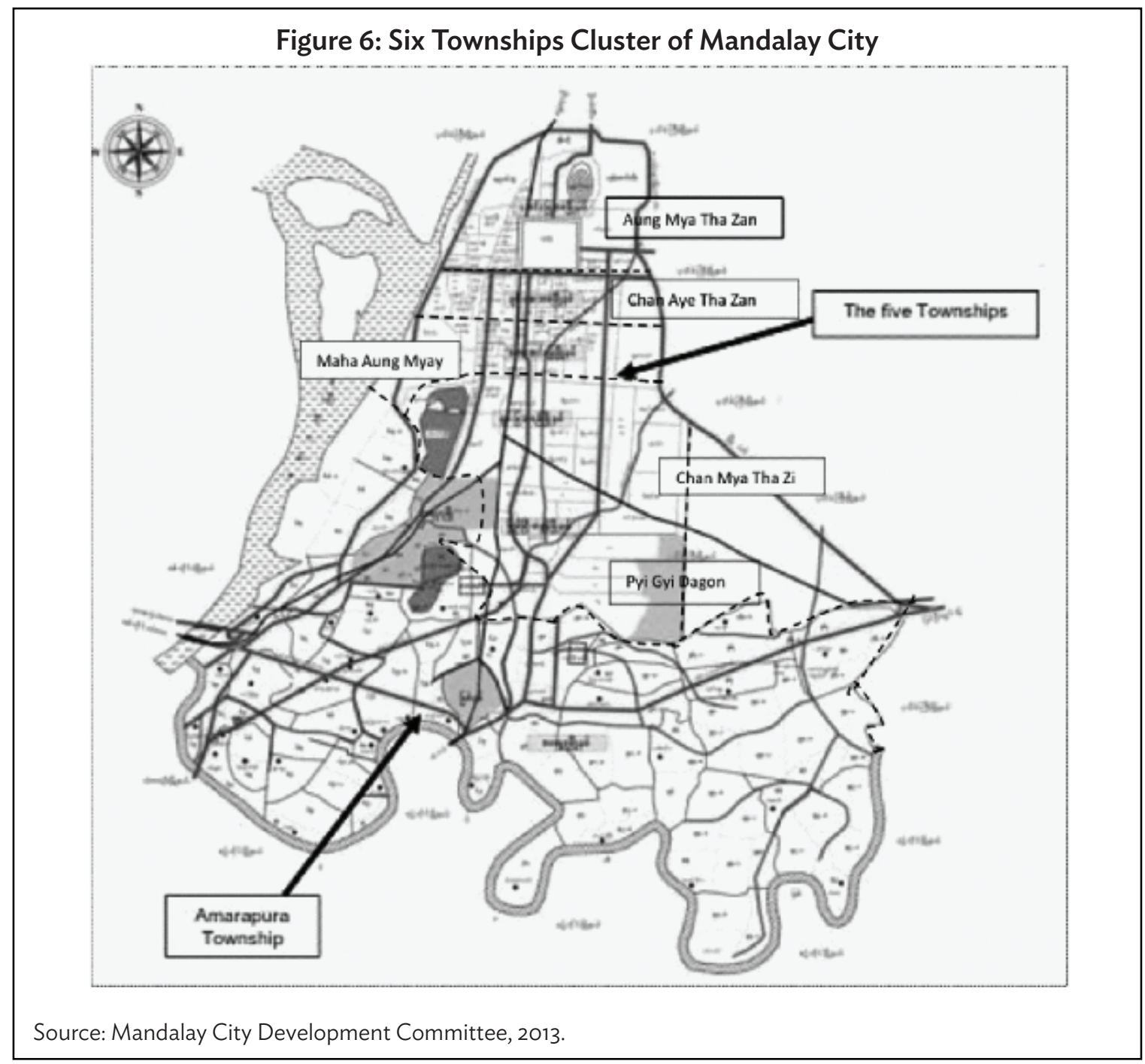

16 ADB. 2013. Myanmar Country Fact Sheet. Manila. 


\section{Housing Needs and Living Conditions}

The present growth of about $2.5 \%$ to $2.9 \%$ is from 6,000 to 7,000 households each year to the population and hence a similar increase in the demand for housing units. This is not to account for the number of substandard houses that need to be rebuilt to bring them to an acceptable standard, nor does it account for the historic backlog in housing units. Public housing construction has been very limited. Priority has been given to housing for government employees as required under the constitution. ${ }^{17}$ However, even here the demand outstrips the supply.

Presently 1,205 public housing units are provided by the regional government in Mandalay region, including four housing estates in Mandalay city, and the rest in Ninja and Maray. In 1984, a very large fire occurred in Mandalay city and over 1,000 households were relocated to plots in Chan Mya Thazi township. From the early 1990s, work started on the resettlement areas in the new town of Pyi Gyi Dagon. Land was allocated in the new settlement areas for government civil servants and low-income households. Many of these resettlement areas were provided with minimal services, usually just a basic road pattern. Drainage, water, road paving, sanitation, and power were not provided. The majority of houses constructed were of woven bamboo matting on a wooden frame, with either palm leaves, bamboo, or zinc sheets. Little has been done to improve the conditions since then.
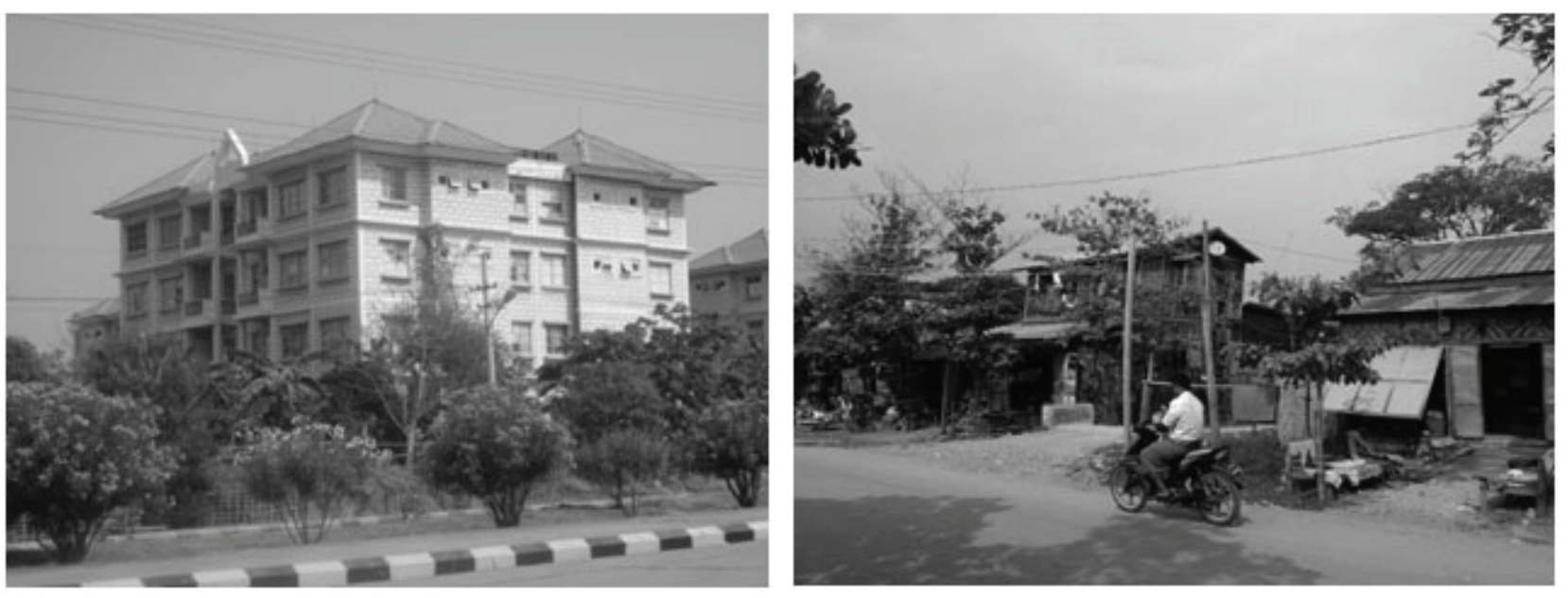

Photos (c) Ramola Naik Singru, 2013.

Given the current level of production, the total formal housing production in Myanmar city is currently about 3,500 additional units per year. While this is quite substantial, it must be set against the demand of at least 6,000 units per year, suggesting a shortfall of 2,500 units, most of which will be met through informal development, thus increasing the numbers of informal households. The first phase of low cost housing being built by the Mandalay City Development Committee is targeting the informal housing population, which has settled illegally on land close to industrial areas in the city. These lands are convenient for the workers in the industries, and also to those providing support services to the residential area around the local industries.

17 The Constitution section 26 (b) states "The Union shall enact necessary laws for Civil Service personnel to have... sufficiency of ....shelter..." 


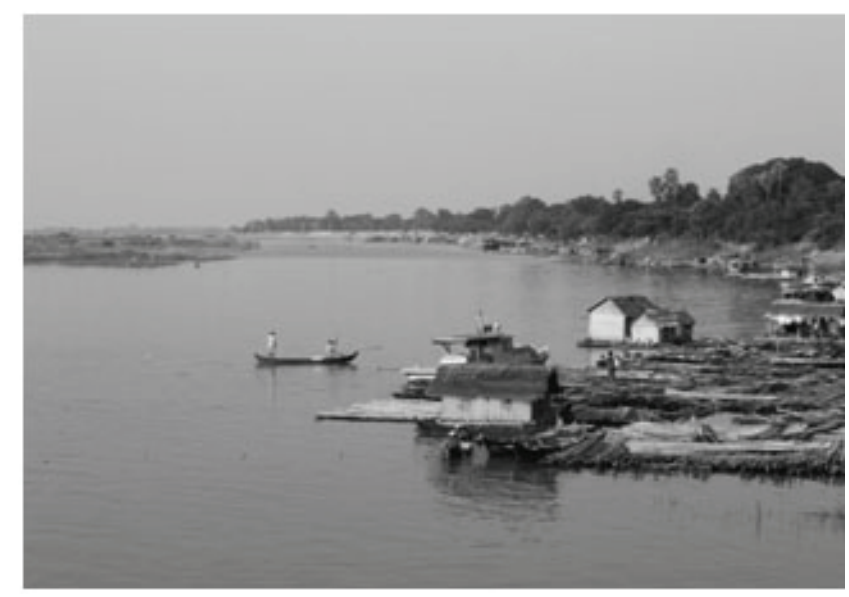

Boat people on temporary floating structures on the River Ayyerwadi.

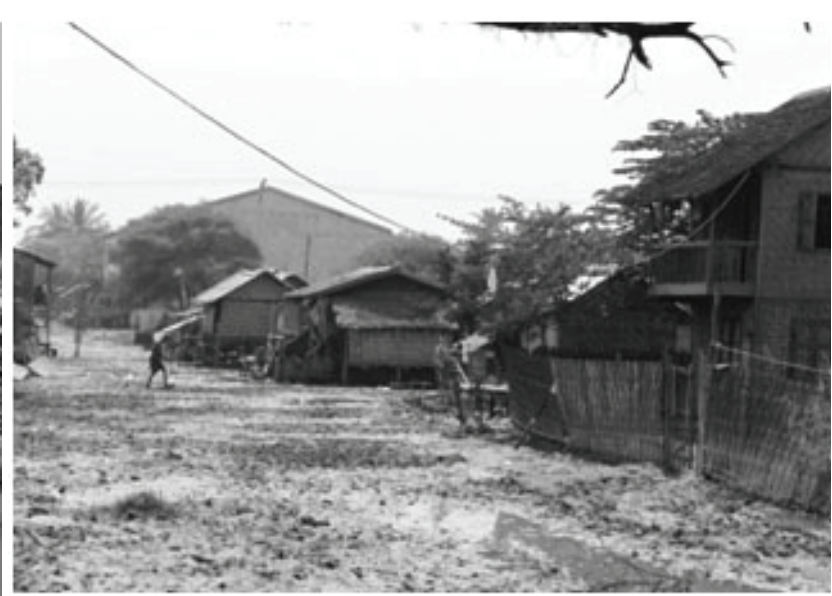

Informal settlements with no access to basic sanitation located near Industrial areas.

Photos (c) Ramola Naik Singru, 2013.

\section{Green City Actions for Clustered City Development}

To achieve the status of a green city, which is also sustainable, inclusive, and competitive, a number of actions were recommended covering investment proposals. Legal and institutional development for each sector include:

(i) Strengthening the spatial planning and building regulations to facilitate the green city approach through clustered city development.

(ii) Establishing the institutional capacity to undertake spatial planning and to approve and monitor development to ensure that it complies with the green city approach for integrated urban regional development and environmental planning.

(iii) Minimizing the carbon footprint of human settlements development by encouraging the use of appropriate technologies in the construction and design of buildings and in the use of water.

(iv) Minimizing the carbon footprint of transport by integrating transport planning with land use planning and by encouraging and facilitating public transport and the use of nonmotorized transport.

(v) Lessening the risk of flooding by improving the solid waste collection and controlling development on natural flood plains, while improving the drainage system and the means of flood mitigation.

(vi) Lessening the pressure on ground water supplies by improving the distribution, regularity, and quality of water, and by developing surface water extraction sources with proper treatment.

(vii) Further minimizing the carbon footprint of urban living by the encouraging residents to practice the $3 R$ s, and controlling the use of plastic bags.

(viii) Minimizing the risk of soil and ground and surface water pollution by initially including appropriate methods of collecting and treating domestic wastewater, but also by treating industrial wastewater and charging the polluters of the basis of polluter pays. 
(ix) Improving the access of the poor to basic services including housing through government subsidized housing, upgrading of settlement areas, and the creation of new low cost housing areas where the infrastructure is in place but the houses are built by the beneficiaries.

The Mandalay Urban Services Improvement Project under preparation with proposed financing from ADB takes forward the recommendations of the green cities scoping study-Toward a Green Mandalay-in the design of the proposed investment loan.

\section{BALANCED URBANIZATION IN VIET NAM}

Viet Nam's population and economy are urbanizing at a fast pace with a structural shift from agriculture to industry and services, which account for nearly $80 \%$ of the economy since $2005 .{ }^{18}$ These sectors are key contributors to urban expansion and the rural to urban transition. Gross domestic product (GDP) growth rate in Viet Nam increased continuously in the last 16 years (1990-2006), reaching $7.6 \%$ in 2007 and $8.5 \%$ in 2008 . The slow growth rate is estimated at $5.5 \%-6 \%$ due to the global economic degradation, while it reached $0 \%$ or negative growth rate in many developed countries. Economic growth of urban centers was relatively stable at $12 \%-15 \%$ on average, and was estimated at 8\%-10\% during 2007-2009. Urban centers took up a relatively high proportion of GDP, reaching $54 \%$ of the whole country when the urban population accounted for $23 \%$ (1998) and reached $70 \%$ of GDP when the urban population occupied 27\% (2005). Unlike most Southeast Asian countries, Viet Nam has relatively low levels of urbanization (23.7\% of the total population of over 76 million). However, this increased rapidly in the 1990 s (Dang, Tacoli, and Thanh 2003). The criteria for urban classification in Viet Nam has not changed since 1990; however reclassification of rural settlements into urban centers, together with migration and natural population growth contributed to Viet Nam's overall increase in urbanization.

\section{Spatial Distribution of the Population}

The spatial distribution of the population across the regions is uneven. The Mekong River Delta is the most heavily populated region ( 16.1 million people, $21 \%$ of the total population), followed by the Red River Delta (14.8 million people, $19.4 \%$ of the population), in a combined land area of less than $16 \%$ of the country's total. By contrast, the central highlands, northwest, and northeast regions account for $45 \%$ of the total land area but only one-fifth of the total population (Dang, Tacoli, and Thanh 2003). The Red River Delta has the highest population density of all (1,180 persons/square kilometer [km²]). Among urban centers, $\mathrm{Ha}$ Noi has the highest population density of 2,909 persons/ $\mathrm{km}^{2}$ followed by Ho Chi Minh City with 2,407 persons $/ \mathrm{km}^{2}$. The Mekong River Delta, the most populous region, has a fairly even population distribution, with population densities in the provinces ranging from 300 to 700 persons $/ \mathrm{km}^{2}$.

18 From 2007 to 2011, Viet Nam's GDP continued to expand, with annual growth rates ranging from $8.5 \%$ in 2007 to $5.9 \%$ in 2011. Ministry of Planning and Investment. 2011. Socio-Economic Development Strategy, 2011-2020. Ha Noi: Ministry of Planning and Investment. 


\section{Viet Nam's Model of Urban Development}

The shift in population distribution and mobility has played an important role in Viet Nam's remarkable success in ensuring high levels of economic growth and in reducing poverty in the last 10 years. Although urban poverty is significantly reduced, inequality in income and access to basic services remain. Pollution, loss of natural capital, low returns on public investments, and low economic competitiveness are some of the urban management challenges. Natural disasters and climateinduced impacts add to the associated social, economic, and environment costs of rapid urbanization, especially in the secondary cities with limited capacity to address consequences of rapid urbanization. According to the National Climate Change Strategy, Viet Nam, since 1963, experienced average temperature rise of $0.5^{\circ} \mathrm{C}-0.7^{\circ} \mathrm{C}$; sea level rise of 20 centimeter; and worsening floods, storms, and droughts. ${ }^{19}$ This is recognized in the Framework Master Plan for Urban Development in Viet Nam to 2025 and Vision to $2050 .{ }^{20}$

The master plan aims to develop secondary cities to divert rural migration away from the large cities toward secondary cities and to foster stronger urban-rural links. It aims to achieve balanced and strategic growth through a national system of capably managed urban centers, envisaging secondary and tertiary cities as development hubs within the provincial context. Viet Nam's strategic choice of developing provincial capital cities, established governance systems, and regional primacy will unlock the economy of the rural hinterlands through providing connectivity and opportunity for growth, thus strengthening the urban-rural links. Developing provincial capital cities as pilots in different geographic regions will boost local economy, balance regional development, strengthen urban-rural links, and address the overcrowding of primary urban centers.

\section{ADB's GrEEEn Cities Initiative and Secondary Cities Development Program}

The challenge for Viet Nam is to maintain its long-term development prospects by minimizing risks associated with urbanization. Adapting critical infrastructure by building climate resilience in coastal and low-lying areas will safeguard vulnerable populations and productive sectors of the economy, including its natural resources.

With urban areas likely to drive economic growth through both rural and regional development, ADB's Secondary Cities Development Program ([SCDP] Green Cities) is financing the improvements in urban and environmental infrastructure and services in three secondary cities of Ha Giang, Hue, and Vinh Yen, facilitating local economic growth and building resilient communities. ${ }^{21}$ SCDP green growth and environmental sustainability focus supports the 10-year strategy from several national programs, namely, the National Green Growth Strategy 2012-2020, the National Action Plan on Climate Change 2012-2020, and the National Program on Urban Development 2011-2020.

Green City Action Plans (GCAPs) developed under the GrEEEn Cities Initiative are informing the investment loan on a results-based lending modality for the cities of Ha Giang, Hue, and Vinh Yen

19 Government of Viet Nam. 2011. No.2139/QD-TTg: Decision on the Approval of the National Climate Change Strategy. Ha Noi. 5 December.

20 Government of Viet Nam, Ministry of Construction. 2009. Framework Master Plan for Urban Development in Viet Nam to 2025 and Vision to 2050. Ha Noi: Ministry of Construction, which has been updated through the "Adjustment of the Master Plan for Urban Development in Viet Nam to 2025 and Vision 2050.” Approved in 2009 under Decision No.445/QĐ-TTg.

21 ADB. 2014. Proposed Results-Based Loan and Administration of Grant for the Secondary Cities Development Program (Green Cities) to the Socialist Republic of Viet Nam. Manila. 
(Figure 4.1). ${ }^{22}$ Hue (Thua Thien Hue province) is one of Viet Nam's heritage (UNESCO) centers. Vinh Yen (Vinh Phuc province) is a satellite town of Ha Noi, strategic for industry situated 20 kilometers away from the international airport and linked to the hinterland with the ADB-financed Lao Cai Expressway strategic connectivity project. Ha Giang (Ha Giang province) is a border town that provides strategic connectivity with the PRC. Thus the SCDP is aimed at developing and demonstrating different urban growth models for climate-resilient and economically competitive cities through the development of GCAPs as investment plans for the cities. The investments are for climate-resilient environmental infrastructure prioritized under the GCAPs; increased community awareness of environmental management; and decision support systems for integrated urban planning and resource management, climate change adaptation, and disaster risk mitigation. An assessment of economic activities and regional economic growth potential has enabled intraregional push-pull analysis to establish a pathway for economic growth and competitiveness within the GrEEEn Cities framework and national policies and strategies for green growth. The GCAPs consider these aspects of inclusive and competitive growth within the regional and national framework and have been developed as time-based investment programs with potential financing solutions. SCDP will thus support the realization of the 10-year socioeconomic development strategy's overall objective of an industrialized Viet Nam in the three cities.

\section{GREATER MEKONG SUBREGION PROGRAM}

\section{Greater Mekong Subregion: Corridor Towns Development and Livelihood Support Projects}

ADB is currently implementing three Greater Mekong Subregion (GMS) loan projects: Cambodia: Southern Economic Corridor Towns Development Project; Lao PDR: East-West Economic Corridor Towns Development Project; and Viet Nam Corridor Towns Development Project. ${ }^{23}$ Furthermore, the ADB project for Livelihood Support for Corridor Towns will assist the urban poor of three selected towns in Cambodia, the Lao PDR, and Viet Nam through microfinance schemes and small market projects that support income generating livelihood activities, and will be implemented parallel to the three GMS loan projects.

\section{Rationale for Corridor Town Development}

The focus on corridor town development is a development approach for balanced regional development that will maximize the economic benefits of increased trade and traffic flows along the major transport corridors in the GMS with the expected positive impacts resulting from accelerated investments in strategically located towns and cities, and added value on economic growth through development oriented on green growth and climate resilience. The objective is to strengthen competitiveness of the GMS economic corridors through investments for the environmental and economic infrastructure with equitable growth.

22 ADB. 2008. Managing Asian Cities. Manila: ADB and ADB. 2014. Proposed Results-Based Loan and Administration of Grant for the Secondary Cities Development Program (Green Cities) to the Socialist Republic of Viet Nam. Manila.

23 ADB. 2012. Report and Recommendation of the President to the Board of Directors: Proposed Loan and Administration of Loan and Grants to the Kingdom of Cambodia for the Greater Mekong Subregion Southern Economic Corridor Towns Development Project. Manila; ADB. 2012. Report and Recommendation of the President to the Board of Directors: Proposed Loan, Grant, and Administration of Grant to the Lao People's Democratic Republic for the Greater Mekong Subregion East-West Economic Corridor Towns Development Project. Manila; and ADB. 2012. Report and Recommendation of the President to the Board of Directors: Proposed Loan and Administration of Grant to the Socialist Republic of Viet Nam for the Greater Mekong Subregion Corridor Towns Development Project. Manila. 
Investments in the three loan projects include environmental infrastructure for access to basic infrastructure; increased urban resilience, and adaptation-mitigation climate change impacts; while the economic infrastructure investments will be for development of markets, logistics centers, dry ports, industrial zones, incubators for small and medium-sized enterprises (SMEs), and tourism development. The impact of the corridor towns development projects would be that these corridor towns will play an important role in enhancing the regional competitiveness of the GMS with the enhancement of economic linkages to their respective hinterlands, which also impact local tourism, and the promotion of local products and value chains. Modern environmental services (water, waste water, solid waste management) result in positive health impacts. Improved climate resilience (flood control measures) will lead to reduced losses from climate change impacts. Thus the improved urban performance of environmental infrastructure will enhance productivity, and increase the attractiveness for investors and residents to support a transition to a green economy.
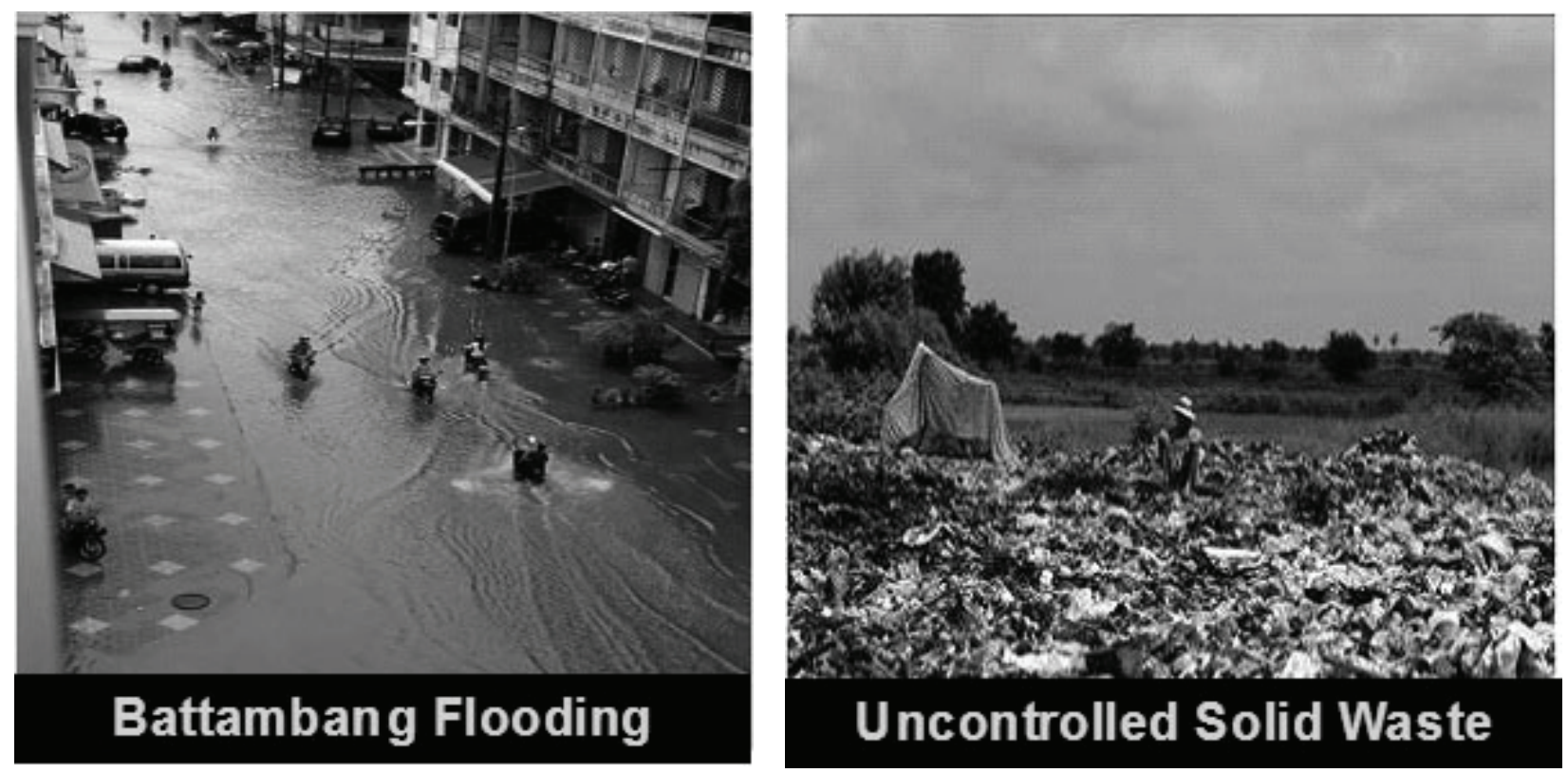

Photo: ADB (F. Steinberg), 2012.

\section{Rationale for Livelihood Support Project}

A number of towns located along the GMS corridors already have strong links with the agricultural hinterlands and natural resource base. The newly emerging border towns have high growth potential to become service centers for the rural agricultural areas, and to provide transport-related services, emerging new industries, and tourism. These developments can contribute to enhanced economic growth and poverty reduction along the economic corridors. The project for Livelihood Support for Corridor Towns is a pilot poverty reduction project in the GMS using a market development approach and will complement the urban infrastructure investments under the three loan projects.

New market trade centers will be established in each of the three project towns: Battambang (Cambodia), Kaysone Phomvihane (the Lao PDR), and Dong Ha (Viet Nam). This benefits market vendors currently working as informal traders, targets the self-employed urban poor population in these towns, and supports the sale of locally produced products. Allocation of market stalls is in through a fair and transparent system with the beneficiaries required to be engaged in informal market vending activities, and be members of the market vendors association. There will also be availability of microfinance to market vendors. 


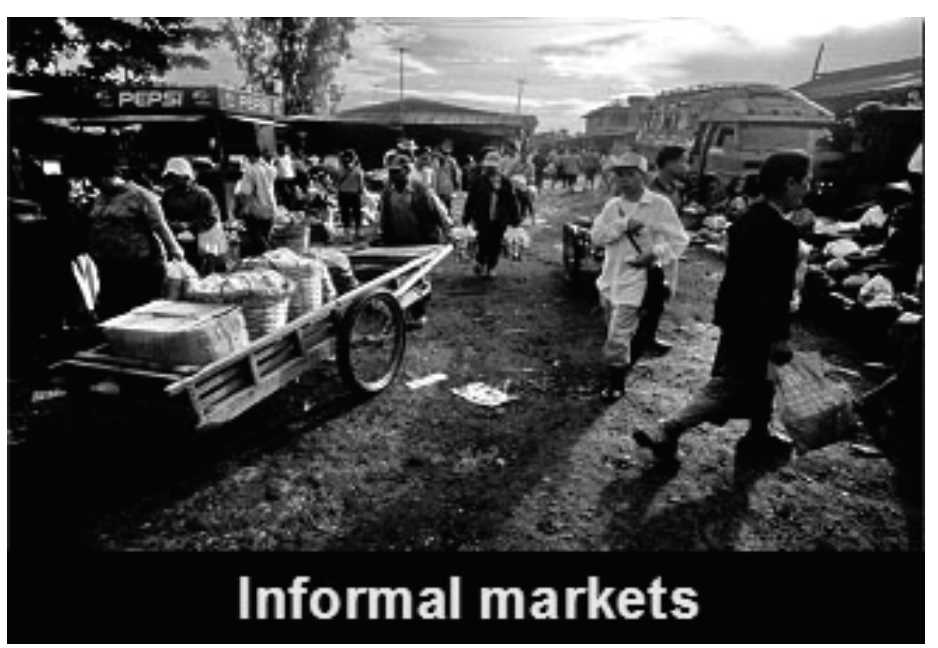

Photo: ADB (F. Steinberg), 2012.

\section{Poverty in Cambodia, the Lao PDR, and Viet Nam}

Poverty remains substantial in Cambodia, the Lao PDR, and Viet Nam, affecting 9\%-34\% of the population. Poverty in Cambodia is widespread with approximately $30 \%$ of the rural population live below the poverty line. During 1992-2007, the overall national poverty incidence in Cambodia declined to about $36 \%$, which is high for the region (the poverty incidence in Viet Nam fell to 20\% during the same period). The distribution of poverty varies considerably in Cambodia, from less than $15 \%$ in the capital to well over $45 \%$ in the northern and northeastern provinces and in the vicinity of Tonle Sap. In Battambang, the poverty incidence in 2009 was 18\%, slightly higher than that in Phnom Penh (15\%) but lower than the approximate national poverty incidence of $36 \%$. Urban poverty also differs from rural poverty because the cost of living reference values differ between urban and rural areas. Poverty in the Lao PDR is still widespread, with an estimated $34 \%$ of the population living below the poverty line and a large proportion of the population at risk of sliding back into poverty. In Savannakhet province, where Kaysone Phomvihane is located, the reported poverty incidence of $43 \%$ exceeds the national rate. Kaysone Phomvihane is also listed among the poorest districts in the Savannakhet province. Poverty is predominantly rural, with high concentrations in the remote and mountainous northeastern and eastern borders with Viet Nam, As a result, poverty also has a strong ethnic association. Viet Nam has made impressive progress in reducing poverty, with the poverty incidence declining from 58\% in 1993 to $10.6 \%$ in 2010. Urban poverty in Viet Nam fell from about 25\% in 1993 to 4\% in 2006. Rural poverty in the same period declined from $66 \%$ to $22 \%$. However, while reductions in urban poverty in Ha Noi and Ho Chi Minh City tend to skew national averages, and cities outside the major growth corridors-including those in the central provinces (e.g., Dak Lak, Pleiku), the Mekong Delta (e.g., Kien Giang. Soc Trang), the northern border (e.g., Cao Bang, Lao Cai), and the central coast (Hue, Quang Tri) - still have relatively high urban poverty rates. In Dong Ha city, poverty incidence in 2010 is $8 \%$, higher than the national urban poverty incidence of $4 \%$, but slightly lower than the overall poverty incidence of $10.6 \%$ in $2010 .{ }^{24}$

24 ADB. 2013. Grant Assistance for the Greater Mekong Subregion: Livelihood Support for Corridor Towns (Financed by the Japan Fund for Poverty Reduction). Grant Assistance Report. Manila. 


\section{GMS Mekong Tourism Development Project}

Tourism is one of nine areas of subregional cooperation under the GMS program entered by the GMS countries in 1992 to promote development through closer economic links. ${ }^{25}$ With the support of ADB and other development partners, the GMS program helps implement subregional projects to reduce poverty and contribute to the conservation of cultural and natural resources in the subregion. Priorities of earlier GMS national tourism development policies include contributing to economic development, promoting the country and its products in the global marketplace, enhancing competitiveness in the tourism sector, and promoting cooperation with neighboring countries. Recent priorities have become notably more pro-poor and include managing and protecting the environment where the poor reside, and ensuring that tourism benefits are spread to the poor and vulnerable groups.

The GMS program's role in tourism development has brought about regional collective actions needed for greater connectivity and integration of tourism plans, programs, and strategies among the GMS countries. The principal goal of GMS regional cooperation strategy and program is to reduce poverty in the Mekong through a $3 \mathrm{C}$ program - enhanced connectivity, increased competitiveness, and greater sense of community.

ADB has provided about $\$ 38.2$ million assistance for the GMS tourism industry; loans comprise $92 \%$ or $\$ 35.0$ million, and technical assistance \$3.2 million. Technical assistance was provided for training, capacity building, preparation of a feasibility study of priority tourism infrastructure projects, and formulation of a GMS regional tourism sector strategy. ${ }^{26}$ ADB lending to the sector consists of three ongoing loans to Cambodia, the Lao PDR, and Viet Nam under the GMS Mekong Tourism Development Project (MTDP), which aims to promote the development of tourism in the Mekong River basin. The specific objective of the MTDP was to promote sustainable tourism development in the lower Mekong River basin through infrastructure improvements, increased community and private sector participation and subregional cooperation. Siem Reap and Phnom Penh from Cambodia were the participating towns in the project.

\section{Siem Reap Environmental Improvement}

In 2001, Siem Reap was a fast growing town that attracted 265,000 international tourists. Many hotels and private houses discharged wastewater into a canal to the west of the town, which was heavily polluted due to lack of maintenance and encroachment by dwellings, which partially block the canal in various places. The wastewater flowed untreated to the Tonle Sap Lake or filtered into the ground, polluting the ground water and creating high risks for the health of the local population and tourists, and for the fragile ecosystem of Tonle Sap Lake.

MTDP rehabilitated the urban sewer on the west side of the town, constructed new connections to the system, constructed stabilizing lagoons to treat discharges from a population of about 17,000 in the west part of the town, and prepared a community sanitation and health awareness program. The MTDP achieved the following results:

(i) International arrivals increased from 264,000 (2002) to 1,305,256 (2012) and rapid increase in tourist volumes was indicative of the positive growth trends, which could be sustained by the improvements in urban environmental conditions due to the project.

\footnotetext{
25 The GMS consists of the following countries: Cambodia, the PRC (Guangxi Zhuang Autonomous Region and Yunnan Province), Lao PDR, Myanmar, Thailand, and Viet Nam.

26 See http://www.adb.org/sites/default/files/institutional-document/33310/files/gms-tourism-assessment.pdf
} 
(ii) Wastewater discharge from residential housing and hotels in the target area were being connected to the new wastewater treatment plant as required by a newly enacted sub-decree. The reduction in flooding and separation of wastewater from storm water in parts of Siem Reap also brought substantial public health benefits.

(iii) Treatment of wastewater, drainage improvements, and more efficient garbage collection and disposal had improved sanitary conditions in urban areas and catalyzed public and private investment in tourism-related infrastructure and services.

(iv) The Project had raised hygiene awareness in Siem Reap and provided access to better sanitation and sewerage services to an estimated 116,318 people in 19,938 households. These reduced communicable disease, lowered health expenditure, and improved productivity.

(v) Land previously flooded was reclaimed and used to establish a night market that sustained fulltime employment for about 200 women vendors and an additional 600 people who supplied the market and provided ancillary services.

(vi) International tourist spending in Siem Reap was estimated at \$504.3 million in 2010. Employment opportunities and remittances for the poor have grown due to the tourism industry. A recent study found that over $75 \%$ of men and women working in Siem Reap and Phnom Penh hotels remit wages of over $\$ 1.2$ million per month with women now represented at least half the tourism industry workforce.

Thus, the improvements in urban environmental infrastructure in Siem Reap promoted increased tourism, livelihoods, and livability of local residents.

\section{STRATEGIC POLICY OPTIONS FOR URBAN-RURAL INTEGRATION AND SUSTAINABLE URBANIZATION}

Based on the learning from Southeast Asia, the following policy options and actions are suggested for urban-rural integration and sustainable urbanization:

\section{Strengthen existing urban settlements through regional balanced development}

(i) Balancing spatial settlement patterns through a focus on decentralization and balanced regional development creates more efficient urbanization centers and reduces spatial disparities that will lead to a sustainable growth. Developing provincial capital cities balance regional development, strengthen urban-rural links, and address overcrowding of primary urban centers.

(ii) Enabling integrated urban-rural spatial policies and planning. Urban spatial policies and urban planning can help foster regional and local economic development to enable integration of economic growth and environmental sustainability at all levels and sectors to improve the quality of life for citizens.

(iii) Decentralizing planning and localizing action. Strengthening the existing urban centers with established regional governance systems enables ownership of actions and boosts the local economy.

(iv) Promote economic competitiveness. Build on the existing natural, human resource, and revenue-generating assets of the city and communities. Enhance the ability to realize the 
full potential of these assets through an enabling policy environment and investments for skills and infrastructure development.

(v) Unlock rural economy through improved connectivity. National urban strategies and policies should enable infrastructure and urban development in existing secondary cities and towns. This will strengthen the existing urban agglomerations drawing urban population toward these secondary centers and take away the pressure from the megacities, thus contributing to a sustainable and inclusive economic growth.

(vi) Build on existing assets and skills. Culture, heritage, industry, and nature are all assets that are often neglected in cities and villages. With culture and tourism playing an important role in a city, joining forces around a shared image of how to develop a city can be enhanced. Building ownership and understanding of the city's assets through consultative and visioning processes can enhance the economic potential of the rural and urban area. In tourism cities, technical aspects such as infrastructure improvements can be combined with the preservation and support of cultural traditions, thereby planning and managing a city's different challenges in an integrated manner. For example, revenue generators such as traditional handicraft and old architecture are cultural and heritage assets that provide authenticity to the tourism industry. These assets need to be supported through investments in heritage conservation, urban upgrading, SME development and capacity trainings to preserve local skills. Traditional skills are often practiced by minority ethnic groups and particularly by women. Economic support policies can be specifically tailored and targeted to be inclusive.

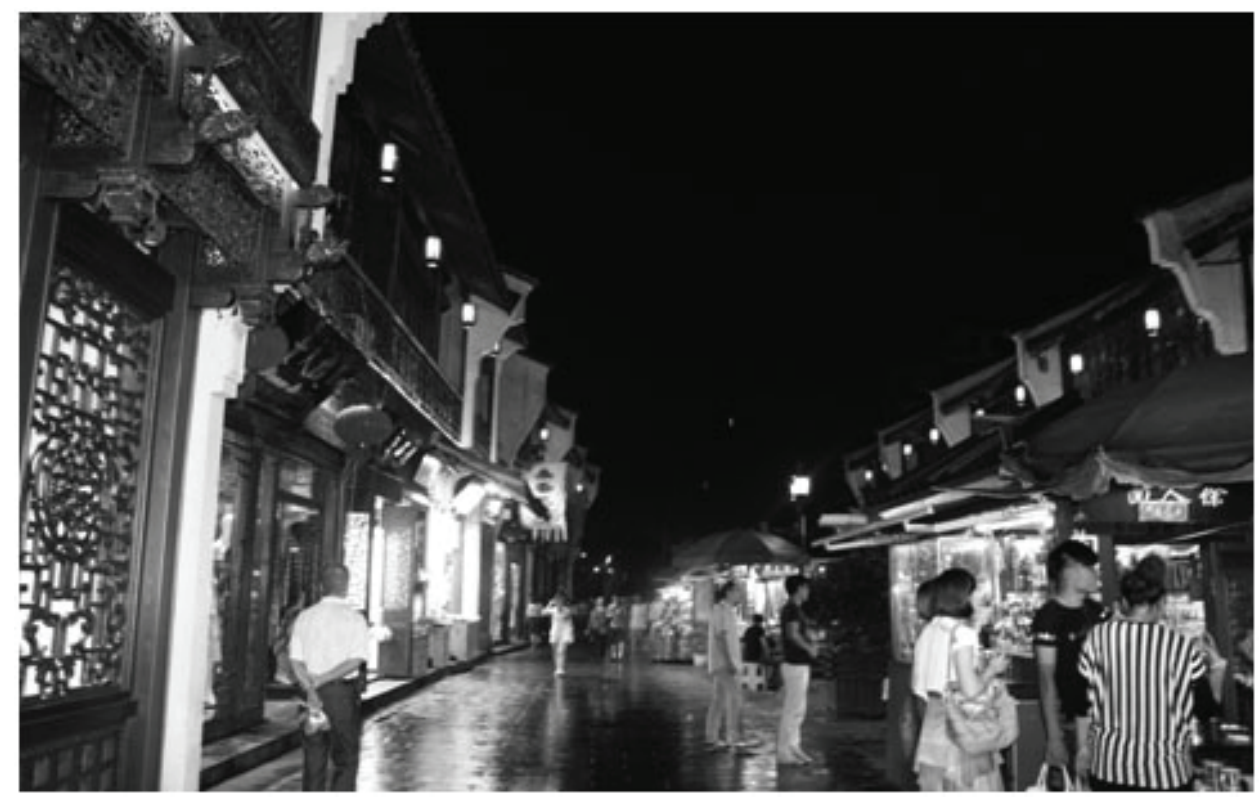

Economically vibrant and well-restored heritage street in Hangzhou, Zheizang province, the People's Republic of China.

Photo (c) Ramola Naik Singru, 2014.

\section{Urban Models of Growth}

New urban models of growth are emerging. Investing in development of these new emerging spatial forms provide valuable lessons for the cities in Southeast Asia to learn from each other. 


\section{Clustered Development}

(i) Supporting clustered economies of small urban areas around the core. Development of a cluster of urban areas or satellite cities around the core urban area provides opportunity for a mutually beneficial relationship between the cities. Cities often develop engulfing specific clusters that may have specialized skills, such as the leather industry in Dharavi in Mumbai or the metal handicrafts industry in Hue in Viet Nam. Unless these specialized industries are provided adequate support to enhance their business practices, streamline environmental practices and connect to relevant markets, the clusters will lose their competitive advantage of being close to the city core.

(ii) Feasible urban infrastructure development and service delivery. Clustered development approach for small towns also enables clustering of infrastructure such as a regional landfill, makes infrastructure financially sustainable for the population sizes.

(iii) Co-benefits of clustered economy.

\section{Satellite Cities}

Megacities will continue to grow but the pressure on these cities can be reduced by providing connectivity and urban infrastructure services to the satellite towns around these large urban agglomerations. Satellite cities are developed through a symbiotic relationship in close proximity to large cities. Rather than being just residential suburbs, satellite cities can become niche market locations in their own right benefiting from the proximity to the large city where a pool of specialized services such as financiers, lawyers, insurers etc. are available. Further, the proximity to a megacity or metropolitan city includes easy access to multinational companies and connectivity to global markets through an international airport. On the other hand the metropolitan area benefits from the manufacturing and secondary services located in the satellite cities with efficient back office operations. Metro Manila has benefited from the location of many business process outsourcing companies located in satellite cities such as Alabang. Vinh Yen, a satellite city of Ha Noi in Viet Nam is aiming to set itself up as the industrial export hub for Viet Nam.

\section{Corridor Town Development}

(i) Enhances economic growth and poverty reduction. The corridor towns can play an important role in enhancing the regional competitiveness by enhancing economic linkages to their respective hinterlands thus enhancing economic growth and leading to poverty reduction.

(ii) Market development approach. Corridor town development improves market connectivity of the hinterland with a positive impact on the local economy, the promotion of local products and value chains, and improved local tourism.

\section{Optimizing Synergistic Cross-Sector Benefits}

Some areas of activity underscore the interrelation between tourism, environmental management, and urban-rural development. The following points highlight some of these areas where synergistic benefits can be achieved.

(i) Supporting SME clusters. A positive development in the tourism sector results in an increased number of visitors and increased spending. SMEs are the backbone of the tourism sector and would benefit directly from such increased numbers. Clustered development can enhance growth in the SME tourism sector. 
(ii) Improving infrastructure and services. The tourism industry, especially with increased numbers of visitors, depends on improved facilities and infrastructure. Such infrastructure is beneficial to both visitors and residents. There are various action areas, ranging from small improvements in signage, public restrooms, and public space management to larger scale improvements in urban design, drainage, and traffic systems. As previous ADB projects have proven, such infrastructure and services improvements provide employment opportunities for residents. Furthermore, the increased number of visitors offers different opportunities for financing the provision, upgrading, and maintenance of infrastructure and services (visitor's tax, fees for use of certain facilities, traffic tolls for tourist buses, etc.), at the same time" replace the sentence with "Simultaneously, there is increased pressure on facilities and infrastructure with the increasing number of visitors which requires systematic planning and management to address this situation proactively.

(iii) Enhancing competencies and capacities through partnerships. At a higher level of skills, there is low capacity even among architects and planners in the GMS region on heritage conservation practices starting with identification, designation, and restoration of conservation zones. Bilateral projects, such as India's engagement in the restoration of the temple complex in Angkor Wat since 1986 and more recently in the restoration of the Ta Prom Temple, have shown that capacities can be built and improved with such institutional cooperation. The GrEEEn City Initiative's concept of Urban Management Partnerships is another example of bringing together more experienced actors in tourism development with other actors willing to learn and apply lessons learnt and best practices. This approach would directly be in line with the objective of increased cooperation and exchange among GMS countries.

Going beyond the traditional perspective of local actors on the one hand and external actors on the other, one also needs to think about tourists in the sense of visitors who might consider staying longer and even investing in the places they visited beforehand. There is some potential of entrepreneurs opening up their own (subsidiary) offices, scaling up their activities, and teaming up with local entrepreneurs. Often these kinds of operations include the training of local staff, directly leading to increased competencies and capacities. For this to happen, the government needs to provide an enabling environment with regard to policies, the regulatory framework, and the provision of infrastructure and services.

(iv) Benefitting socioeconomic development. Tourism is an important instrument in socioeconomic development, as social contacts between tourists and locals increase mutual understanding and cultural exchange. Additionally, integrated urban development should be based on participatory processes and the buy-in of key stakeholders. The specific development of a sustainable tourism industry and location could bring several benefits: increased numbers (and higher spending) of visitors, growth in an economically high-potential niche market (which is on the rise in Asia), environmentally and financially more efficient resource use due to improved infrastructure systems, increased environmental quality and livability for visitors and residents.

The city governments in collaboration with development partners, private sector, and civil society can thus take the lead in optimizing cross-sector synergies to enhance urban-urban integrated development based on a shared vision of how urbanization and economic growth can be achieved in an environmentally friendly, socially inclusive, and financially viable manner. 


\section{REFERENCES}

ADB. 2008. Managing Asian Cities. Manila: Asian Development Bank.

_-_. 2011. Asia 2050: Realizing the Asian Century. Manila: Asian Development Bank.

- - 2012. Key Indicators 2012: Green Urbanization in Asia. Manila: Asian Development Bank.

- - . 2014. Toward a Green Mandalay: Scoping Study for a Strategic Development Plan for Mandalay. Final Report. Manila (TA8251-MYA).

D. Baharoglu and C. Kessides. 2002. Urban Poverty. In Jeni Klugman, ed. A Sourcebook for Poverty Reduction Strategies. Washington, DC: World Bank.

J. L. Baker. 2008. Urban poverty: a global view. Urban Papers; no. UP-5. Washington, DC: World Bank. http://documents.worldbank.org/curated/en/2008/01/9112288/urban-poverty-global-view.

N. A. Dang, C. Tacoli, and H. X. Thanh. 2003. Migration in Vietnam: A review of information on current trends. Regional Conference on Migration, Development and Pro-Poor Policy Choices in Asia. Dhaka: Refugee and Migratory Movements Research Unit and Department for International Development (DFID), UK.

Government of the Republic of the Philippines, National Statistics Office. 2010. Census of Population and Housing (CPH). Explanatory Text, Manila: National Statistics Office.

Government of the Socialist Republic of Viet Nam. 2001. DECREE No. 72/2001/ND-CP of October 5 , 2001 on the Classification of Urban Centers and Urban Management levels. Ha Noi:

Government of the Socialist Republic of Viet Nam.

M. Lindfield and F. Steinberg. 2011. Inclusive Cities. Manila: Asian Development Bank.

R. Naik Singru. 2007. Mumbai: Spatial Segregation in a 'Globalising' city. In Ranvinder S. Sandhu and Jasmeet Sandhu, eds. Globalization and Inequality in Developing Countries. 131-172. New Delhi: Rawat Publications.

- - 2008. Democracy, Competitive Governance and Spatial transformation in 'globalising'

Mumbai. ISA World Forum of Sociology. Barcelona: International Sociological Association.

- - . 2008b. Restructuring Asia's urban landscape: Policy driven or transformation led? ISA-RC21 Conference on Landscapes of Global Urbanism: Power, Marginality, and Creativity. Tokyo: ISARC21.

R. Naik Singru and M. Lindfield. 2014. Republic of the Philippines: National Urban Assessment. Manila: Asian Development Bank.

R. Naik Singru and M. Lindfield. 2015. Forthcoming. Inclusive Cities Toolkit. Manila: Asian Development Bank.

S. Sandhu and R. Naik Singru. 2014. Enabling GrEEEn Cities: An Operational Framework for Integrated

D. Sattherthwaite and C. Tacoli. 2003. The urban part of rural development: the role of small and intermediate urban centres in rural and regional development and poverty reduction. Working Paper Series on Rural-Urban Interactions and Livelihood Strategies. No. 9. London: International Institute for Environment and Development.

Urban Development in Southeast Asia. Working Paper Series No. 9. Southeast Asia Department, Manila: Asian Development Bank.

United Nations. 2002. World Urbanization Prospects, The 2001 Revision. New York: Population Division, Department of Economic and Social Affairs, United Nations, ST/ESA/SER.A/216.

UN-Habitat. 2009. Planning Sustainable Cities: Global Report on Human Settlements. Global Report on Sustainable Settlements. Nairobi: UN-Habitat.

World Bank. 2011. Data Urban Development. http://data.worldbank.org/topic/urban-development

World Bank. 2013. Global Monitoring Report 2013: Rural-Urban Dynamics and the Millennium Development Goals. Washington, DC: World Bank. 


\section{Regional Balanced Urbanization for Inclusive Cities Development Urban-Rural Poverty Linkages in Secondary Cities Development in Southeast Asia}

The impact of urbanization on growth and equality, and on urban and rural poverty are well-documented but do not discuss alternative models of urbanization. While the relationship between urbanization and growth (and poverty reduction in general) is often well-established, less is discussed about the forms and causes of newly emerging urban poverty and exclusion, and how they differ for different city sizes. This paper analyzes the potential for poverty reduction with balanced regional urbanization through the development of second-tier cities and secondary towns in Southeast Asia. It discusses the spatial growth patterns that have an impact on sustainable development and urban-rural poverty linkages and suggests policy options and actions for urban-rural integration and sustainable urbanization. It proposes strategies for sustainable urban development through a regional balanced development approach using different urban growth models to reduce spatial disparities and optimize cross-sector synergies.

\section{About the Asian Development Bank}

ADB's vision is an Asia and Pacific region free of poverty. Its mission is to help its developing member countries reduce poverty and improve the quality of life of their people. Despite the region's many successes, it remains home to the majority of the world's poor. ADB is committed to reducing poverty through inclusive economic growth, environmentally sustainable growth, and regional integration.

Based in Manila, ADB is owned by 67 members, including 48 from the region. Its main instruments for helping its developing member countries are policy dialogue, loans, equity investments, guarantees, grants, and technical assistance. 